\title{
A Review of Low-Voltage Renewable Microgrids: Generation Forecasting and Demand-Side Management Strategies
}

\author{
Miguel Aybar-Mejía ${ }^{1}\left(\mathbb{D}\right.$, Junior Villanueva ${ }^{2}$, Deyslen Mariano-Hernández ${ }^{1} \mathbb{D}$, Félix Santos $^{3} \mathbb{D}$ \\ and Angel Molina-García 2,*(D) \\ 1 Engineering Area, Instituto Tecnológico de Santo Domingo, Santo Domingo 10602, Dominican Republic; \\ miguel.aybar@intec.edu.do (M.A.-M.); deyslen.mariano@intec.edu.do (D.M.-H.) \\ 2 Department of Automatics, Electrical Engineering and Electronic Technology, Universidad Politecnica de \\ Cartagena, 30202 Cartagena, Spain; junior.villanueva@edu.upct.es \\ 3 Fundamental and Environmental Science Area, Instituto Tecnológico de Santo Domingo, \\ Santo Domingo 10602, Dominican Republic; felix.santos@intec.edu.do \\ * Correspondence: angel.molina@upct.es
}

check for

updates

Citation: Aybar-Mejía, M.;

Villanueva, J.; Mariano-Hernández D.;

Santos, F.; Molina-García, A. A

Review of Low-Voltage Renewable

Microgrids: Generation Forecasting and Demand-Side Management Strategies. Electronics 2021, 10, 2093. https://doi.org/10.3390/

electronics10172093

Academic Editor: Amr Radwan

Received: 12 July 2021

Accepted: 25 August 2021

Published: 29 August 2021

Publisher's Note: MDPI stays neutral with regard to jurisdictional claims in published maps and institutional affiliations.

Copyright: (c) 2021 by the authors. Licensee MDPI, Basel, Switzerland. This article is an open access article distributed under the terms and conditions of the Creative Commons Attribution (CC BY) license (https:// creativecommons.org/licenses/by/ $4.0 /)$.

\begin{abstract}
It is expected that distribution power systems will soon be able to connect a variety of microgrids from residential, commercial, and industrial users, and thus integrate a variety of distributed generation technologies, mainly renewable energy sources to supply their demands. Indeed, some authors affirm that distribution networks will propose significant changes as a consequence of this massive integration of microgrids at the distribution level. Under this scenario, the control of distributed generation inverters, demand management systems, renewable resource forecasting, and demand predictions will allow better integration of such microgrid clusters to decongest power systems. This paper presents a review of microgrids connected at distribution networks and the solutions that facilitate their integration into such distribution network level, such as demand management systems, renewable resource forecasting, and demand predictions. Recent contributions focused on the application of microgrids in Low-Voltage distribution networks are also analyzed and reviewed in detail. In addition, this paper provides a critical review of the most relevant challenges currently facing electrical distribution networks, with an explicit focus on the massive interconnection of electrical microgrids and the future with relevant renewable energy source integration.
\end{abstract}

Keywords: control inverter; demand-side management; energy management; low voltage configuration; microgrids

\section{Introduction}

A microgrid (MG) is a small-scale electrical energy network characterized by distributed generation (DG), such as photovoltaic (PV) solar panels [1], wind turbines (WT), heat and power generators (CHP), and other components of control units, manageable loads, and storage units [2]. To achieve a suitable integration between renewable energy technologies and energy storage systems (ESS), it is necessary to include energy management schemes (EMS) that allow strategies for avoiding inappropriate costs in an MG. Moreover, both RE and ESS play an essential role in the costs of implementing a microgrid [3]. Regarding control and management systems, MGs can operate in two modes: (i) when it is interconnected to a grid and (ii) in islanding mode [4], the latter of which requires the maintenance of demand and generation balance, according to energy availability over time [5]. When an MG is connected to a power system at a common coupling point (PCC), it is possible to interact with the electrical distribution network and the operator of this network (DSO), providing generation or demanding power from the grid. Under islanding mode, the MG is disconnected from the corresponding power system, maintaining quality energy services to some critical loads with demand management and control. It can also forecast available generation resources and propose some demand response strategies. 
The electrical loads within MGs are typically elements demanding power. They can be composed of a lighting system, a heating ventilation and air conditioning (HVAC) system, residential appliances, industrial loads, plug-in electric vehicles (PEV), a storage system, and other equipment [6].

Residential customers represent an essential part of world energy consumption. Subsequently, MG implementation is increasing to provide distribution networks with a more efficient control and management system in this consumption sector [7]. Fiorini [8] explains how EMS can monitor, measure, and control the energy consumption and production of a system - such as an MG - through control algorithms that can model all possible conditions throughout a given microgrid. Among the conditions, these algorithms must evaluate the availability of energy resources, the status of the storage system, the conditions of the loads or consumption, environmental impact, economic indicators, the status of the network, and the flow of energy from said network. For this reason, the integration of EMS benefits both the end-users of energy and generators and the administrators of electrical transmission and distribution networks. Though the integration of renewable technologies and modern equipment into energy systems has increased, so too have the costs of energy production; these have become a challenge for each country. Demand-side management (DSM) is used to mitigate this challenge. This strategy allows one to control and monitor an end user's energy consumption. Therefore, DSM can manipulate end-users' demands for electricity [9]. The benefits provided by distributed generation and microgrids in the electrical distribution network currently suppose a relevant target due to increases in the interconnection of energy resources that are distributed in Low-Voltage (LV) networks [10].

Most contributions to this field have focused on MG, and they are based predominantly on simulation software. This is a faster and cheaper solution than real case studies, avoiding any experimental system implementation. The elements and components used to simulate supply-side and demand-side scenarios in residential, commercial, and industrial sectors are then defined and emulated. Nevertheless, other contributions are based on real implementation case studies, as can be seen in Table 1. MG implementation thus comprises a remarkable number of contributions and results that allow for easier analysis of this system's integration into distribution networks. Therefore, there are still some opportunities that should be developed and improved accordingly:

- How interconnected electrical microgrids in electrical distribution systems allow passive systems to become active electrical distribution networks. A literary review of projects related to electrical microgrids implemented in distribution networks allows us to analyze trends regarding their integration into electrical systems.

- Explain and analyze why the trend of using microgrids in electrical distribution networks and how they allow the transition from passive energy distribution systems to active systems

- The prediction of resources in energy production is a highly developed component within the field of generation. However, when it is applied to a distributed generation system, forecasting allows both network operators and final energy users to project their systems and infer network decongestion. This situation is due to microgrids supplying interconnected local demands. 
Table 1. Microgrid case studies; LV distribution networks.

\begin{tabular}{|c|c|c|c|c|c|c|}
\hline Ref. & Year & Location Component & System & Control Microgrid & Type System & Management \\
\hline [11] & 2017 & Columbus, Ohio & PV, WT, TESS & - & Building & - \\
\hline [12] & 2017 & Sydney & PV, WT, ESS, STC & - & $\begin{array}{l}\text { Commercial } \\
\text { Building }\end{array}$ & Optimal EMS \\
\hline [13] & 2017 & $\begin{array}{l}\text { University of British } \\
\text { Columbia }\end{array}$ & PV ESS, & Harmonics detection & $\begin{array}{c}\text { Campus, } \\
\text { hibryd AC-DC }\end{array}$ & EMS \\
\hline [14] & 2017 & $\begin{array}{l}\text { EE. UU, Kayenta } \\
\text { Health Center }\end{array}$ & $\begin{array}{l}\text { PV, Diesel Generators, } \\
\text { emergency power } \\
\text { supply system (EPSS) }\end{array}$ & $\begin{array}{l}\text { MPPT conotrol P-O. } \\
\text { Static Transfer Switch }\end{array}$ & $\begin{array}{l}\text { Health care } \\
\text { building }\end{array}$ & $\begin{array}{l}\text { All equipment } \\
\text { are critical, } \\
\text { don't have } \\
\text { DSM }\end{array}$ \\
\hline [15] & 2018 & $\begin{array}{l}\text { Italy, Electric Power } \\
\text { System laboratory of } \\
\text { Politecnico di Bari }\end{array}$ & $\begin{array}{c}\text { PV, WT, ESS, } \\
\text { Gas-fueled internal } \\
\text { combustion engine in } \\
\text { cogeneration, gas } \\
\text { microturbine in } \\
\text { cogeneration layout }\end{array}$ & - & $\begin{array}{l}\text { Comercial/ } \\
\text { Education }\end{array}$ & - \\
\hline [16] & 2018 & University of Seville & FC & $\begin{array}{l}\text { Model Predictive } \\
\text { Control }\end{array}$ & Education & $\begin{array}{l}\text { Model } \\
\text { Predictive } \\
\text { Control }\end{array}$ \\
\hline [17] & 2018 & Bilbao & PV, ESS & $\begin{array}{c}\text { Perturb and Observe } \\
\text { algorithm }(\mathrm{P} \& \mathrm{O}) \text { for } \\
\mathrm{MPPT}\end{array}$ & $\begin{array}{l}\text { Building } \\
\text { housing }\end{array}$ & - \\
\hline [9] & 2018 & $\begin{array}{l}\text { Graciosa Island in the } \\
\text { Canary Islands }\end{array}$ & PV, ESS & $\begin{array}{c}\text { nonlinear } \\
\text { mathematical } \\
\text { programming model }\end{array}$ & $\begin{array}{l}\text { smart } \\
\text { microgrid } \\
\text { district }\end{array}$ & $\begin{array}{l}\text { Game Theory } \\
\text { for Microgrids }\end{array}$ \\
\hline [18] & 2018 & Brooklyn, New York & PV & $\begin{array}{l}\text { blockchain-based } \\
\text { information systems }\end{array}$ & $\begin{array}{l}\text { residential } \\
\text { community }\end{array}$ & $\begin{array}{c}\text { Energy } \\
\text { management } \\
\text { trading system } \\
\text { (EMTS) }\end{array}$ \\
\hline [19] & 2018 & Venice, Italy & $\begin{array}{l}\text { PV, biodiesel } \\
\text { engine-generator } \\
(\mathrm{BDEG}), \mathrm{ESS}\end{array}$ & $\begin{array}{l}\text { blockchain-based } \\
\text { information systems }\end{array}$ & $\begin{array}{l}\text { Industrial } \\
\text { community }\end{array}$ & $\begin{array}{c}\text { power } \\
\text { management } \\
\text { systems (PMSs) }\end{array}$ \\
\hline [20] & 2018 & Australia & PV, ESS & $\begin{array}{l}\text { Primary, secondary, } \\
\text { tertiary }\end{array}$ & Campus & $\begin{array}{l}\text { Time of Use } \\
\text { (ToU) tariffs, } \\
\text { load level and } \\
\text { State of Charge } \\
\text { (SOC) of battery, } \\
\text { EMS decides }\end{array}$ \\
\hline [21] & 2019 & Finland & PV, WT, ESS & $\begin{array}{l}\text { Flexibility for HVAC } \\
\text { and Electric water heat } \\
(\text { EWH) loads }\end{array}$ & $\begin{array}{l}\text { Residential } \\
\text { community }\end{array}$ & Home EMS \\
\hline [22] & 2020 & Coimbra, Portugal & PV, ESS & BMS-V2B & Campus & $\begin{array}{c}\text { Building } \\
\text { Management } \\
\text { System (BMS). }\end{array}$ \\
\hline
\end{tabular}

There are several revisions about MGs in the field of control and operation [23-25]; interconnection with the distribution network [26-29]; sustainable trends to apply the MG in the distribution network [30], or MG management [31]. However, and to the best of the authors' knowledge, there is a lack of revisions focused on MG interconnections in LV distribution electrical networks. In this framework, the DSOs should be able to integrate customer demand, interconnected MGs, and bidirectional power flows into such LowVoltage distribution networks with remarkable renewable integration. Therefore, and based on recent contributions, this paper reviews critical aspects regarding MG interconnection 
in LV distribution networks, such as demand and generation management and renewable energy source forecasting technologies. In addition, the advantages and challenges of integrating distributed generation resources into MGs at LV level are also discussed. Some technical implementation limits and drawbacks are also reviewed. This work thus aims to establish the following points:

- A critical review of electrical MG implementation at the LV distribution network.

- An analysis of the relevance of demand and generation forecasting solutions in electrical MGs for their operation and management.

- A detailed discussion of demand management programs to provide a more efficient scenario of renewable energy source integration into MGs.

- A revision of current solutions to facilitate MG integration and avoid relevant additional power system investments.

This paper is structured as follows: Section 2 presents the methodology. Section 3 describes LV MG configurations and advantages of LV MGs over existing conventional network, Section 4 discusses generation and demand forecasting approaches, Section 5 reviews recent LV MG management and control strategies, and demand-side management programs for LV MGs (load displacement) are reviewed in Section 6; Section 7 comprises the discussion; and Section 8 examines our conclusion and future challenges for the industry.

\section{Methodology}

For the development of this review, the following methodology is proposed and used by the authors:

1. Data collection: several searches were carried out in the ScienceDirect, IEEE, and GoogleScholar databases according to keywords, types of articles, and publication time searching criteria. The keywords used for the searching process were Microgrid, Low-Voltage, Residential, Configuration, Commercial, industries, among others. The types of publications selected were relevant research works and thematic reviews. From this initial classification process, the most relevant contributions were taken from the selected databases, according to the requirements set for the development of the document.

2. Selection and filtering of information: the references were ordered in a bibliographic manager, we proceeded to filter the information by keywords, title, and abstract to organize the information by relevance. Indeed, the identified contributions were classified according to the sections developed in this work, such as the configurations of LV distribution networks with integrated MGs, generation and demand forecasting approaches, LV MG management and control, as well as demand-side management programs for LV MGs.

3. Distribution of topics to be reviewed: by analyzing the information of the selected contributions. The relationship among the selected topics with significant similarity and relevance is identified and discussed.

4. Analysis of selected information: through a critical analysis of the references, being then possible to infer the conclusions presented in this work.

Figure 1 displays a general scheme of the methodology proposed for this review. 


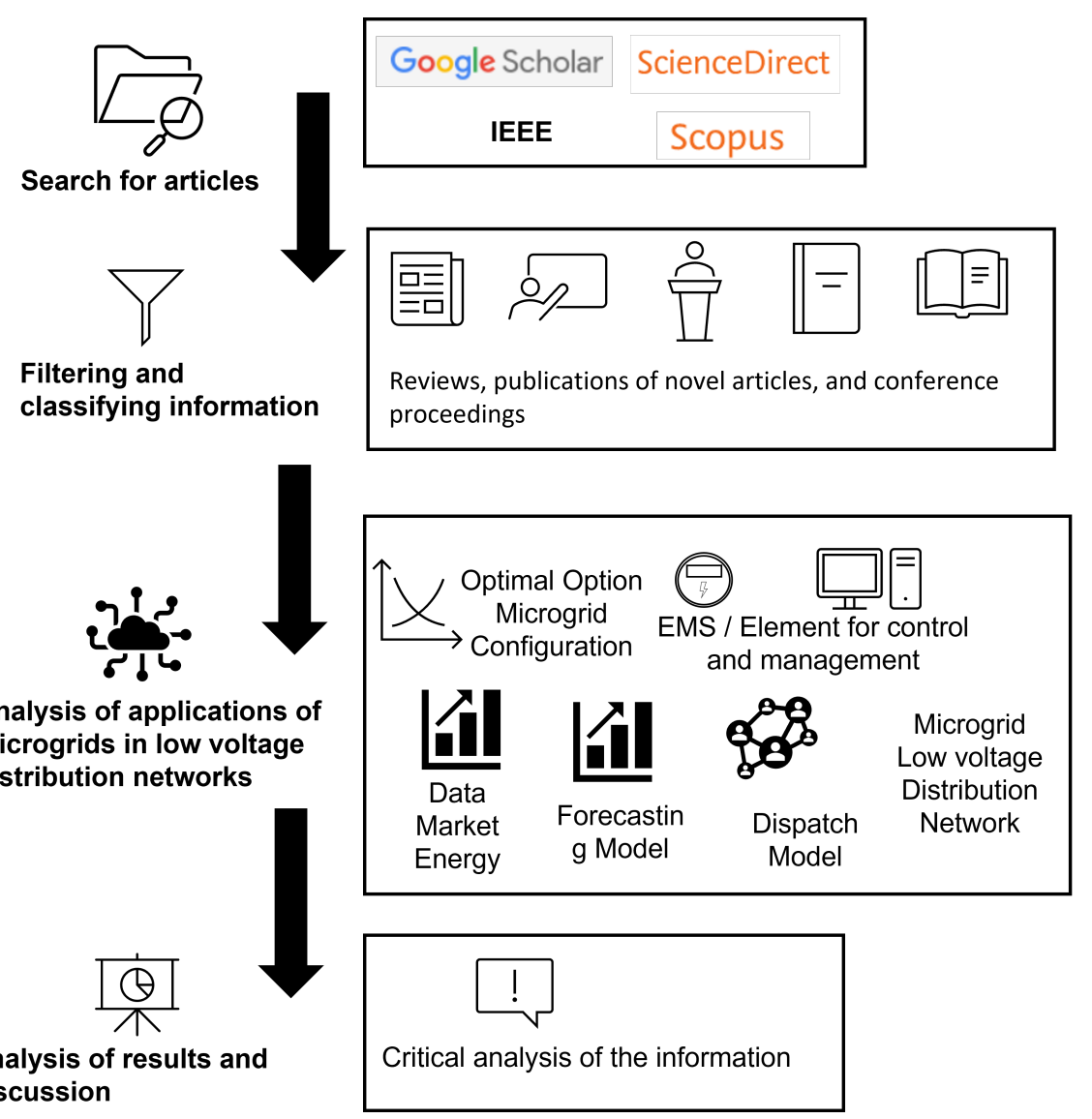

Figure 1. Proposed methodology, general scheme.

\section{Low-Voltage Microgrids}

According to the field-specific literature, MGs can be classified depending on different parameters, such as level of voltage, supervisory and management control, type of interconnection phases, and type of application. Xu et al. [32] describe the characteristics of the different microgrid configurations presented in Figure 2. Hirsch [11] explains the advantages of applying MG campus/institutional, which can be used for demand reduction and optimization of the demand profile according to energy resources. In addition, MG military application can also give energy security in critical infrastructures. Remote MGs are used in regions with poor access to public energy services, such as rural areas. Finally, MG applications in distribution networks (residential, commercial, and industrial) allow for the integration of customers as individual prosumers. Moreover, groups of prosumers are able to communicate and provide greater stability at the LV level without significant investment in these networks. Furthermore, LV MGs commonly combine renewable energy sources [33], PV installations [34,35], electric vehicle charging [36,37], and hybrid storage systems [38], aiming to provide auxiliary services for local LV networks [39,40]. Recently, multi-microgrid systems provide additional reliability of distribution systems and enhance system resiliency under contingencies [41]. According to the American National Standard ANSI C84.1, voltages in an electrical system can be classified by the criteria depicted in Table 2. MGs connected to LV distribution networks can then be used to supply residential buildings, low-demand industrial buildings, low-demand commercial buildings, and low-demand buildings. 


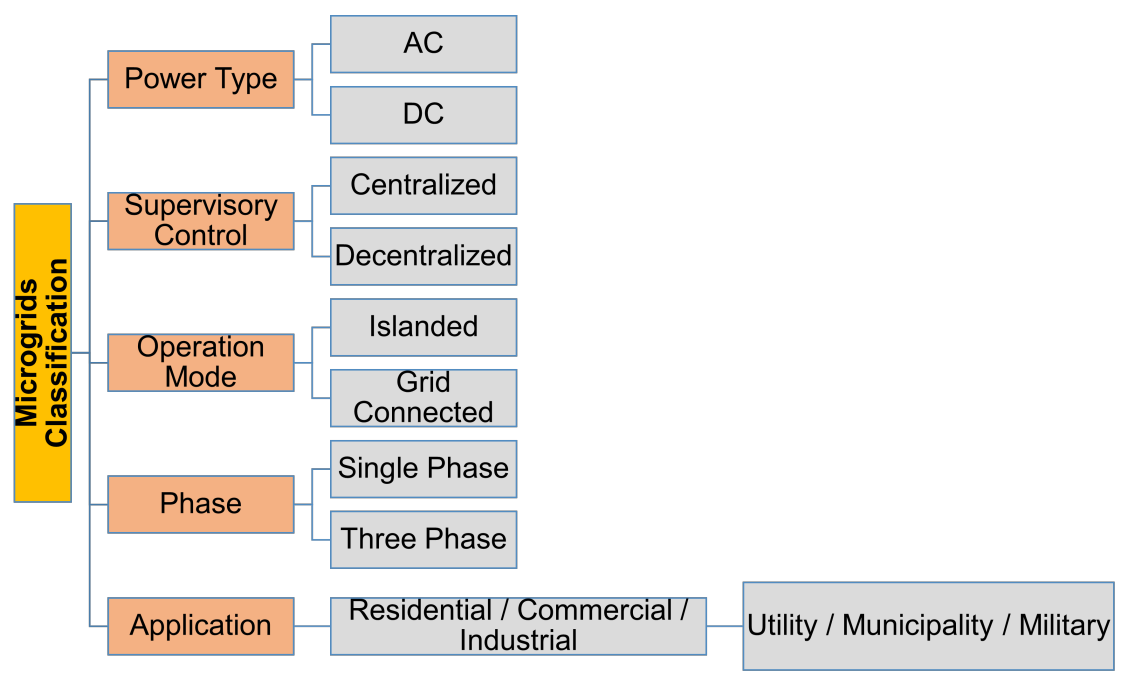

Figure 2. Microgrids classification.

Table 2. Range voltage according ANSI C84.1.

\begin{tabular}{cc}
\hline Voltage Class & Range \\
\hline Low voltage (LV) & $\leq 1000 \mathrm{~V}$ \\
Medium voltage (MV) & $>1000 \mathrm{~V}$ and $\leq 100 \mathrm{kV}$ \\
High voltage (HV) & $>100 \mathrm{kV}$ and $\leq 230 \mathrm{kV}$ \\
Extra high voltage (EHV) & $>230 \mathrm{kV}$ and $\leq 1000 \mathrm{kV}$ \\
Ultra high voltage (UHV) & $>1000 \mathrm{kV}$ \\
\hline
\end{tabular}

Rebollal et al. [42], in their review of norms and standards used in MGs and distributed generation, compare parameters that should be used to evaluate the interconnection and disconnection states of MGs in the downstream network. These parameters should be considered in addition to the tolerances and values allowed for electrical grid-codes, such as voltage, frequency, response time, synchronization, power factor, and steadystate among other conditions. Among the international standards analyzed, they include IEC/IEEE/PAS 63547, IEEE 929, IEEE 1547, UNE/EN/IEC 62109, IEC 62898-1, IEC 628982, IEC 62898-3-1, and IEEE P2030.8. Note that it is necessary to develop a technical framework to converge all the technical suggestions given by these international standards. Although other protocols are used to automatize power systems and implement them in MGs - such as DNP3 and IEC104; they are no longer in use due to the implementation of IEC61850, used for automation of power transformation centers and electrical distribution networks [43].

The use of MGs in LV distribution networks has the following advantages, over existing conventional LV networks:

- Any direct dependence on public networks to supply the local demand connected to the LV distribution network is avoided. MGs also reduce the distribution system's losses, since the loads are closer to the source of microgeneration [44]. Electrical storage systems can also be located close to the demand and the interconnection bus [45]. Moreover, the integration of a peer-to-peer (P2P) system promotes the purchase of energy from among MGs, reducing distribution losses and increasing network operation efficiency [46].

- MGs are able to be contingency systems in the distribution network and energy management [47], minimizing losses and improving the voltage profile according to the load connected to the network [48,49]. MGs also allow for changing the traditional distribution network configuration from a radial to mesh layout [50]. This reconfiguration improves the $\mathrm{LV}$ distribution network response, being able to restore the network under technical failures [51]. 
- MGs allow both integration and control of the different EV technologies connected to the LV distribution network for optimal charging and discharging processes, depending on the needs of the LV distribution network operator [52]. In addition, MGs allow managing the power flow within the LV distribution network [53], becoming a link between the distributed generation and the distribution network [54].

- MGs are elements of the LV distribution network that, through appropriate incentives, can become mechanisms to regulate voltage and frequency within such LV distribution networks [55]. MGs thus guarantee a reliable electricity supply to customers [56], being considered as a backup supply source in the event of a mains power outage [57]. From their different generation sources, MGs have the ability to allow the LV distribution network to adapt accordingly under extreme atmospheric and weather events [58]. In addition, MGs also allow the programming and configuration of distribution networks as a demand response program [59].

- MGs reduce greenhouse gas emissions from LV distributed generation connected to the distribution network by managing their energy resources. Therefore, MGs are positively in line with the Sustainable Development Goals (SDG). More specifically, Goal 7 focused on obtaining access to accessible, reliable, sustainable, and modern energy [60].

\section{Generation and Demand Forecasting Approaches}

Effective energy balancing relies upon two fundamental factors: (i) the corresponding energy generation reserve that can be specified to the power station, and (ii) the expected demand and renewable generation forecasting [61]. Forecasting at the MG level has developed significantly in recent years [62], and it has enhanced both the management and the use of conventional and renewable energy sources within MGs. Moreover, financial matters of energy trade with other MGs and the main grid can also be improved [63]. Nevertheless, and due to the variability of renewable resources [64] and the need to decide how much generation power is used from controllable assets [65], the main objectives of most forecasting methods at the MG level are focused on estimating both renewable resources and demand simultaneously. Forecasting of energy resources is required by the MGS, since they mainly depend on such sustainable resources. These resources can be inconsistent due to the fact that they rely on stochastic boundaries, such as solar irradiance, climate, and wind speed [66]. On the other hand, energy demand forecasting is needed to make microgrids possible and proficient in their determination of likely electric demand [67]. Forecasting processes can be carried out at different time intervals, such as very short-term (seconds to hours), short-term (hours to one week), medium-term (weeks to a month), and long-term (months to a year) [68]. Nonetheless, the short-term time interval is mainly used in relation to an MG's ideal activity [69]. The forecasting accuracy of energy demand and renewable resources plays a fundamental role in successful exchanges on electricity markets [70]. The accuracy of these approaches is usually evaluated by a variety of metrics, such as mean absolute error (MAE), mean absolute percentage error (MAPE), and root mean squared error (RMSE) [71]. Other performance metrics that are not widely used are correlation coefficient $(\mathrm{R})$, mean bias error (MBE), mean relative error (MRE), and mean square error (MSE). A review and comparison of these metrics can be found in [72].

Recent studies focused on forecasting energy resources are summarized in Table 3. In addition, forecasting demand contributions are given in Table 4 . In these studies, different forecasting approaches—such as machine learning [73-79], deep learning [80-86], and ensemble learning $[87,88]$ - are used and implemented for evaluation. Note that the ideal approach relies upon the application, necessary horizon, and time step; hence, various procedures can be effectively executed [89]. 
Table 3. Renewable energy resources forecasting: a comparison of approaches.

\begin{tabular}{|c|c|c|c|c|c|}
\hline Ref. & Year & Forecasting Horizon & Forecasting Approach & Forecasting Model & Forecast Accuracy \\
\hline [79] & 2017 & Hours & Machine learning & Back propagation neural network & MAPE \\
\hline [76] & 2018 & Hours & Machine learning & Artificial neural network & RMSE \\
\hline [78] & 2019 & Hours & Machine learning & Adaptive neuro fuzzy interfence & $\begin{array}{l}\text { RMSE, MAE, MSE, } \\
\text { MBE, RME }\end{array}$ \\
\hline [75] & 2019 & Hours & Machine learning & $\begin{array}{c}\text { Physical hybrid artificial } \\
\text { neural network }\end{array}$ & MAE, RMSE \\
\hline [83] & 2019 & Hours & Ensemble learning & $\begin{array}{l}\text { Long short-term memory } \\
\text { recurrent neural network, } \\
\text { feed-forward neural network }\end{array}$ & RMSE \\
\hline [87] & 2019 & Day & Deep learning & $\begin{array}{l}\text { Long short-term memory } \\
\text { recurrent neural network }\end{array}$ & RMSE, MAE \\
\hline [80] & 2019 & Hours & Deep learning & $\begin{array}{l}\text { Multi-headed convolutional } \\
\text { neural network }\end{array}$ & $\begin{array}{l}\text { MBE, RMSE, } \\
\text { MAPE, MAE }\end{array}$ \\
\hline [86] & 2019 & Hours & Deep learning & $\begin{array}{l}\text { Deep recurrent neural network, } \\
\text { Long short-term memory }\end{array}$ & $\begin{array}{l}\text { RMSE, MAPE, } \\
\text { MAE }\end{array}$ \\
\hline [66] & 2020 & Hours & Machine learning & Artificial neural network & MAPE, MSE \\
\hline [77] & 2020 & Minutes & Machine learning & Artificial neural network & RMSE \\
\hline
\end{tabular}

Table 4. Energy demand forecasting: a comparison of approaches.

\begin{tabular}{|c|c|c|c|c|c|}
\hline Ref. & Year & Forecasting Horizon & Forecasting Approach & Forecasting Model & Forecast Accuracy \\
\hline$[63]$ & 2018 & Day & Machine learning & Neuro fuzzy inference & $\begin{array}{l}\text { RMSE, MAE, } \\
\text { MAPE }\end{array}$ \\
\hline [74] & 2019 & Hours & Machine learning & $\begin{array}{c}k \text {-neighbors, Self-organizing } \\
\text { maps }\end{array}$ & MAPE \\
\hline [73] & 2019 & Day & Machine learning & Support vector machine & RMSE, MAE \\
\hline [88] & 2019 & Hours & Ensemble learning & $\begin{array}{c}\text { GBRT, Xgboost, Decision tree, } \\
\text { Seq2Seq }\end{array}$ & MAE, RMSE \\
\hline [81] & 2019 & Hours & Deep learning & $\begin{array}{l}\text { Long short-term memory } \\
\text { recurrent neural network }\end{array}$ & MAE, MAPE \\
\hline [69] & 2020 & Hours & Ensemble learning & $\begin{array}{l}\text { Support vector regression, Long } \\
\text { short-term memory }\end{array}$ & $\begin{array}{l}\text { RMSE, MAE, } \\
\text { MAPE, MSE, R }\end{array}$ \\
\hline [85] & 2020 & Hours & Deep learning & $\begin{array}{l}\text { Long short-term memory } \\
\text { recurrent neural network }\end{array}$ & MSE \\
\hline [82] & 2020 & Hours & Deep learning & $\begin{array}{l}\text { Multi-layer perceptron artificial } \\
\text { neural network }\end{array}$ & RMSE, MSE, R \\
\hline [84] & 2021 & Hours & Deep learning & $\begin{array}{l}\text { Bidirectional long short-term } \\
\text { memory }\end{array}$ & RMSE, MSE, R \\
\hline
\end{tabular}

\section{Low-Voltage Microgrid Management and Control}

Samadi et al. [90] affirm that the two most important challenges affecting MG operation are: (i) the development of intelligent controls for the MG elements, allowing them to work within an optimal range; and (ii) optimal energy management system (EMS) to maintain stability between generation and demand. The EMS of an MG is in charge of verifying and monitoring the energy flow between each element connected to MG [91]. In addition, the EMS is based on verifying the status of the distributed generation system, the status of the load, the operation of the system, the operating and maintenance costs, the technical and economic restrictions of the system [92], the reduction in the amount of GHG emis- 
sions [93], and the status and operating costs of ESS [31]. Figure 3 depicts the information exchanged between the EMS and the rest of the system. Harmouch et al. [94] identify three categories of EMS: (i) centralized EMS applied for a specific rule, (ii) decentralized EMS, and (iii) distributed EMS. Decentralized and distributed EMS have more flexibility for the operation of a group of MGs. EMS can be configured as autonomous and grid-connected to an MG network, with different operational requirements. A grid-connected EMS aims to obtain the highest income according to the market. An EMS in autonomous mode meets a user's needs by controlling the loads connected to the MG [95]. Recent studies, summarized in Table 5, use EMS systems to connect MGs at LV distribution networks.

Table 5. EMS system in a microgrid: Low-Voltage networks.

\begin{tabular}{|c|c|c|c|c|}
\hline Ref. & Year & System Component & EMS & Type Microgrid \\
\hline [92] & 2018 & PV, WT, VE & $\begin{array}{l}\text { Optimization model compare the state } \\
\text { of charge of the two storage systems }\end{array}$ & Home with V2G \\
\hline [94] & 2018 & $\begin{array}{l}\text { PV, WT, BESS, Critical loads that are } \\
\text { not controllable, controllable loads }\end{array}$ & $\begin{array}{c}\text { Decentralized multi-agent EMS } \\
\text { (DMA-EMS) }\end{array}$ & $\begin{array}{l}\text { Cluster multiple } \\
\text { microgrid }\end{array}$ \\
\hline [96] & 2018 & $\begin{array}{l}\text { PV, WT, BESS, combined cooling heat } \\
\text { power } \mu \text {-CCHP unit, TESS, }\end{array}$ & Genetic algorithm & Industrial \\
\hline [97] & 2018 & $\begin{array}{c}\text { BSSS, EV, PV, WT, Electrical } \\
\text { controllable loads (ECL), Thermal } \\
\text { controllable (TCL) loads such as } \\
\text { refrigerator (REF), air conditioner (AC) } \\
\text { and electric water heater (EWH) }\end{array}$ & $\begin{array}{l}\text { Two-stage mixed-integer linear } \\
\text { programming (MILP) }\end{array}$ & Home \\
\hline [98] & 2018 & $\begin{array}{l}\text { BSSS, EV, PV, WT, curtailable loads, } \\
\text { shiftable loads }\end{array}$ & $\begin{array}{l}\text { Stochastic model predictive control } \\
\text { (SMPC) }\end{array}$ & Community \\
\hline [99] & 2019 & PV, WT, BESS & $\begin{array}{l}\text { Model predictive power and voltage } \\
\text { control (MPPVC) method }\end{array}$ & Hybrid AC-DC \\
\hline [100] & 2019 & PV, BESS & $\begin{array}{c}\text { Adaptive neuro fuzzy inference } \\
\text { system (ANFIS), Training by } \\
\text { clustering and neuro-fuzzy Min-Max } \\
\text { classifier }\end{array}$ & Multiple \\
\hline [101] & 2019 & PV, WT, BESS, Fixed Load & $\begin{array}{c}\text { economical storage management } \\
\text { system (ESMS) }\end{array}$ & Home microgrid \\
\hline [102] & 2019 & PV, WT, BESS & $\begin{array}{l}\text { method of Lagrange multipliers and } \\
\text { power scheduling algorithm with } \\
\text { dynamic programming (DP) }\end{array}$ & Home microgrid \\
\hline$[90]$ & 2019 & PV, WT, DIESEL, MT, FC, ESSS & $\begin{array}{c}\text { EMS based on multi-agent systems } \\
\text { MAS }\end{array}$ & Multiple microgrid \\
\hline [103] & 2019 & $\begin{array}{l}\text { PV, WT, BESSS, Phosphoric Acid Fuel } \\
\text { Cell (PAFC), Micro-gas Turbine (MT), } \\
\text { and electrical storage as Battery } \\
\text { Energy Storage System (BESS) }\end{array}$ & $\begin{array}{l}\text { Modified Particle Swarm } \\
\text { Optimization }\end{array}$ & Community Microgrid \\
\hline [104] & 2020 & PV, WIND & Self-evolving type-2 fuzzy logic & Multiple microgrid \\
\hline [105] & 2020 & PV, WIND & $\begin{array}{l}\text { Rolling Time Horizon RTH-based } \\
\text { EMS. }\end{array}$ & Home with \\
\hline [106] & 2021 & PV, WT, BESS & $\begin{array}{l}\text { hierarchical energy management } \\
\text { system (HEMS) }\end{array}$ & Home Microgrid \\
\hline [107] & 2021 & $\begin{array}{l}\text { PV, WT, BESS, Hybrid Energy Storage } \\
\text { System (HESS), Thermal and electrical } \\
\text { loads }\end{array}$ & Fuzzy Logic Control (FLC) & Home Microgrid \\
\hline [108] & 2021 & $\begin{array}{l}\text { PV, WT, microturbine, solid-oxide fuel } \\
\text { cell (SOFC) }\end{array}$ & Based on frequency control & Home community \\
\hline [109] & 2021 & PV, BESS & Decentralized field (MF) control & Home Microgrid \\
\hline [95] & 2021 & PV, WT, FC, Microturbine (MT) , BESS & Quantum particle swarm optimization & Multiple microgrid \\
\hline [93] & 2021 & $\begin{array}{l}\text { PV, fuel cell (FC), micro-turbine (MT), } \\
\text { diesel generator (DE), battery ESS }\end{array}$ & $\begin{array}{l}\text { Optimization navigator (BARON) } \\
\text { algorithm }\end{array}$ & Multiple microgrid \\
\hline
\end{tabular}




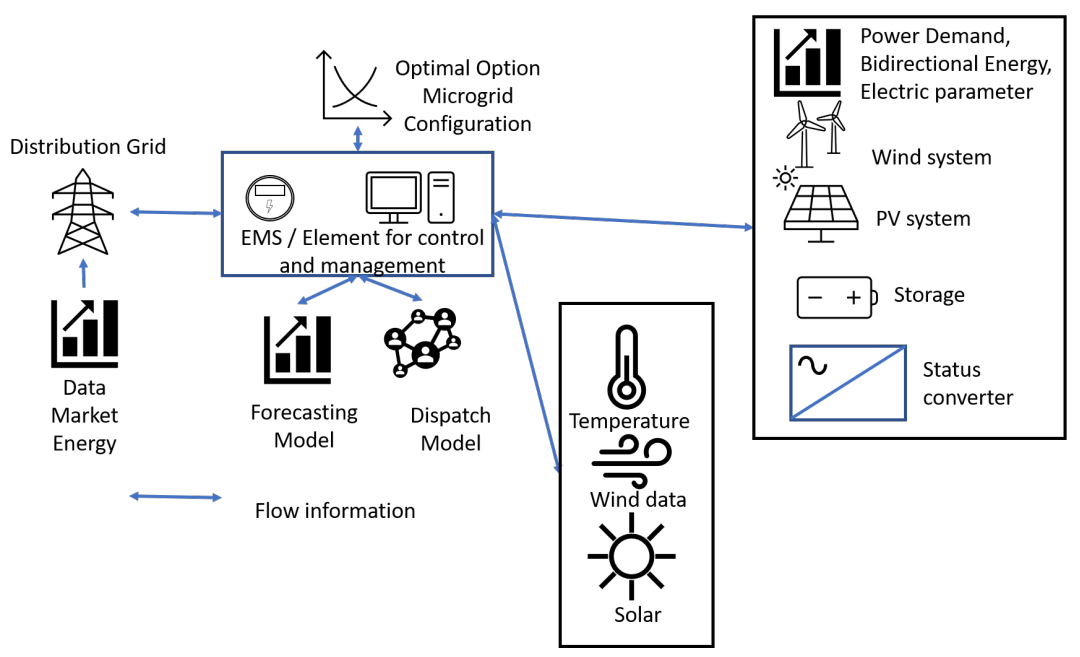

Figure 3. EMS information flow.

With regard to renewable energy sources, both standalone and combined renewables must be connected to the power systems through DC-DC and/or DC-AC power converter topology [110]. Power converters are defined as a kind of electronic circuit used for energy conversion that convert electrical energy from a certain supply into energy suitable for loads (e.g., voltage or current with suitable frequency and/or amplitude) [111]. With the current displacement of synchronous generators by inverter-based sources supplied by renewables [112], larger frequency deviations, due to lower rotating inertial energy, have emerged as additional drawbacks to be solved by providing ancillary services from renewables [113] and MGs [114]. There are two types of converters in MGs: grid-followers and grid-formers (see Figure 4); grid-tied inverters operate as grid-following sources tracking the voltage angle of the grid to control output. Nevertheless, and even with inverter fast frequency support, frequency regulation still depends on the remaining synchronous generators [115]. Table 6 summarizes and compares the characteristics of recent contributions focused on grid-following methods for MGs. In addition, Tables 7 and 8 summarize recent control strategy approaches for residential power inverters with voltage levels lower than $1000 \mathrm{~V}$.

\section{Grid Following Inverter}
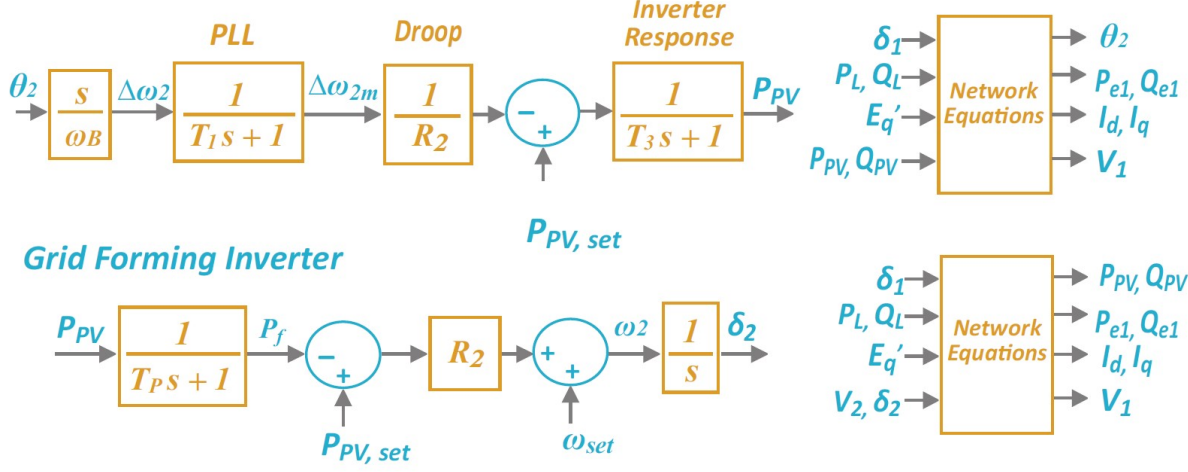

Figure 4. Grid-following and grid-forming inverter models. 
Table 6. Analysis of contributions based on grid-following inverter MG control.

\begin{tabular}{|c|c|c|c|}
\hline Refs. & Control Method & Advantages & Drawbacks/Challenges \\
\hline$[116-138]$ & Droop Control & $\begin{array}{l}\text { No need for communication } \\
\text { link, excellent flexibility, high } \\
\text { reliability, easy } \\
\text { implementation, and a } \\
\text { combination of a variety of } \\
\text { DGs with different } \\
\text { power ratings }\end{array}$ & $\begin{array}{l}\text { Compromise between } \\
\text { voltage/frequency } \\
\text { regulation and power } \\
\text { sharing, feeding under } \\
\text { unbalanced conditions, } \\
\text { harmonic load sharing and } \\
\text { voltage harmonic } \\
\text { compensation, coupling } \\
\text { inductances, line impedance, } \\
\text { renewable energy sources, } \\
\text { active and reactive power } \\
\text { sharing, load dependency, } \\
\text { and islanding } \\
\text { detection algorithm. }\end{array}$ \\
\hline$[118,119,127,130,139-141]$ & Central control & $\begin{array}{l}\text { Current sharing is perfect } \\
\text { even during the transient } \\
\text { phase, different power rating } \\
\text { inverters can be connected } \\
\text { without changing the control } \\
\text { structure, and voltage } \\
\text { regulation. }\end{array}$ & $\begin{array}{l}\text { The high cost of } \\
\text { communication } \\
\text { infrastructure installing. } \\
\text { Difficult to handle } \\
\text { nonlinear loads. }\end{array}$ \\
\hline $\begin{array}{c}{[119,121,124,127,130,132,135,138} \\
139,141-149]\end{array}$ & Master/Slave Control & $\begin{array}{c}\text { Transfer of information } \\
\text { between the master controller } \\
\text { and the slave's controllers. } \\
\text { Reduction of the complexity } \\
\text { and the cost while increasing } \\
\text { the reliability. }\end{array}$ & $\begin{array}{l}\text { If the master unit fails, } \\
\text { the whole system will fail. }\end{array}$ \\
\hline$[118,129,132,136,139-142,149-157]$ & $\begin{array}{l}\text { Averaging Control for } \\
\text { Voltage Regulation and } \\
\text { Current Sharing }\end{array}$ & $\begin{array}{l}\text { All the inverters in the } \\
\text { microgrid take part in the } \\
\text { voltage, frequency, as well as } \\
\text { the current regulation, } \\
\text { demonstrating the democratic } \\
\text { nature of this controller. }\end{array}$ & $\begin{array}{l}\text { Need for optimization of the } \\
\text { grid power management, } \\
\text { current sharing, and the } \\
\text { voltage control issues. }\end{array}$ \\
\hline$[118-120,139,158-163]$ & Angle Droop Control & $\begin{array}{l}\text { Capable to regulate system } \\
\text { frequency to its set point } \\
\text { without any steady state error } \\
\text { and no communication } \\
\text { channel between sources } \\
\text { allowing for reducing the } \\
\text { frequency deviation and } \\
\text { improving the voltage quality } \\
\text { and enhancing reliability. } \\
\text { Likewise, it ensures that } \\
\text { appropriate power sharing } \\
\text { can be performed under } \\
\text { weakness conditions of the } \\
\text { system by choosing a high } \\
\text { angle gain. This method also } \\
\text { agrees with harmonic power } \\
\text { sharing among DERs. }\end{array}$ & $\begin{array}{l}\text { the selection the high angle } \\
\text { gain has a negative effect on } \\
\text { system stability, } \\
\text { the inaccurate real and } \\
\text { reactive power sharing and } \\
\text { GPS communications. Lack } \\
\text { of synchronism between DG } \\
\text { and low dynamics and slow } \\
\text { response in some cases. }\end{array}$ \\
\hline$[118,139,164-172]$ & Multi Agent System (MAS) & $\begin{array}{l}\text { Agent independency reducing } \\
\text { the need for information } \\
\text { manipulating, increasing the } \\
\text { reliability and robustness of } \\
\text { the control system, plug and } \\
\text { play capability, and learning } \\
\text { agents can be taught previous } \\
\text { behaviors by themselves. }\end{array}$ & $\begin{array}{l}\text { Stability of voltage and } \\
\text { frequency along increasing } \\
\text { scheduling duration. }\end{array}$ \\
\hline
\end{tabular}


Table 7. Inverter control approaches (I).

\begin{tabular}{|c|c|c|c|c|}
\hline Ref. & Year & Power Control & Control Equations & Control Targets \\
\hline [173] & 2021 & $\begin{array}{l}\text { Autonomous droop control } \\
\text { (ADC) and decentralized } \\
\text { optimal control (DOC) }\end{array}$ & $\begin{array}{c}P_{P V}=\min (M P P, \text { Pdroop }) \\
Q_{p v}=Q_{d r o o p}\end{array}$ & $\begin{array}{l}\text { Keeping bus voltage, power } \\
\text { factor range and power capacity. } \\
\text { Voltage limit } \leq 1.095 \mathrm{pu}\end{array}$ \\
\hline [174] & 2020 & $\begin{array}{l}\text { The droop method: } \\
\text { hierarchical (primary, } \\
\text { secondary, and tertiary) control } \\
\text { method }\end{array}$ & $\begin{array}{l}\omega_{i}=\omega_{\text {nom }}-m_{i} P_{i} \\
\quad V_{i}=V_{\text {nom }}-n_{i} Q_{i}\end{array}$ & $\begin{array}{l}\text { Droop control strategy derived } \\
\text { from integrator current sharing } \\
\text { designed and improved. }\end{array}$ \\
\hline [175] & 2020 & $\begin{array}{l}\text { Two voltage control methods: } \\
P \text { control and } P Q \text { control }\end{array}$ & $\frac{g \cdot V_{n o m}}{n \cdot(n+1) / 2}=(R P+X Q) \cdot \sum_{j=1}^{n} \frac{1}{\hat{V}_{j}}$ & $\begin{array}{l}P \text { control reduces active power } \\
\text { output when the inverter voltage } \\
\text { exceeds the specific upper } \\
\text { voltage limit. } P Q \text { control, first, } \\
\text { supplies reactive power to } \\
\text { reduce the voltage rise }\end{array}$ \\
\hline [176] & 2020 & $\begin{array}{l}\text { Finite control set FCS model } \\
\text { predictive control (MPC). } \\
\text { Droop control }\end{array}$ & $\begin{aligned} {\left[\begin{array}{l}V_{c} \\
I_{f}\end{array}\right] } & =A_{d}\left[\begin{array}{c}V_{c} \\
I_{j}\end{array}\right]^{k}+B_{d}\left[\begin{array}{l}V_{i} \\
I_{0}\end{array}\right] \\
A_{q} & =e^{A T_{s}} ; B_{d}=\int_{0}^{T_{s}} e^{A_{\tau}} B d \tau\end{aligned}$ & $\begin{array}{c}P \text { offers a wide range of } \\
\text { operation and } \\
\text { adaptation flexibility }\end{array}$ \\
\hline [177] & 2020 & $\begin{array}{l}\text { PI controllers and integrate } \\
\text { Cost Optimization Based } \\
\text { Microgrid EMS Using Genetic } \\
\text { Algorithm (GA) }\end{array}$ & $\operatorname{Min}(J)=\sum_{t=0}^{T} C_{u_{\text {grid }}}+P_{u_{\text {grid }}}$ & $\begin{array}{c}\text { Loss reduction strategy, operated } \\
\text { with an automatic centralized } \\
\text { controller, designed with the IEC } \\
62040-3 \text { standard }\end{array}$ \\
\hline [178] & 2020 & $\begin{array}{l}\text { The load side PC (LPC) and } \\
\text { machine side PC (MPC) }\end{array}$ & $\begin{array}{r}i_{q_{r e f}}(n)=i_{q_{r e f}}(n-1)+ \\
k_{i}\left(\omega_{\text {err-mod }}(n-1)\right)+ \\
k_{p}\left(\omega_{\text {err }-\bmod }(n)\right)\end{array}$ & $\begin{array}{l}\text { Offers a wide range of operation } \\
\text { and adaptation flexibility }\end{array}$ \\
\hline [179] & 2020 & $\begin{array}{l}\text { Drop control with Newton's } \\
\text { algorithm for island operation }\end{array}$ & $\left(\begin{array}{l}\Delta_{p} \\
\Delta_{q}\end{array}\right)=\left(\begin{array}{ll}D^{P^{\theta}} & D^{P^{v}} \\
Q^{Q^{\theta}} & D^{Q^{v}}\end{array}\right)\left(\begin{array}{c}\Delta \theta \\
\Delta v\end{array}\right)$ & $\begin{array}{l}\text { Algorithm for the power flow for } \\
\text { small signal stability } \\
\text { of microgrids }\end{array}$ \\
\hline [180] & 2020 & $\begin{array}{l}\text { Inter-phase power transfer } \\
\text { with droop control }\end{array}$ & $\begin{array}{l}P_{\text {load }}>\left(P_{P V}^{M P P T}+P_{\text {bat }}^{\max }+\right. \\
\left.P_{\text {droop }}^{\max }\right) \mid \phi_{x} ; \\
S O C_{\text {min }} \leq S O C \leq S O C_{\max }\end{array}$ & $\begin{array}{l}\text { Intra-phase power } \\
\text { management strategy }\end{array}$ \\
\hline [181] & 2019 & $\begin{array}{l}\text { Single-phase control strategy. } \\
\text { PV, Group or residences }\end{array}$ & $\begin{array}{l}I_{x p}=g_{1_{p}} \hat{v}_{x} \cdot e^{\theta j_{x}} \\
\quad I_{x q}=g_{1_{q}} \hat{v}_{x} \cdot e^{\theta j_{x}-\frac{\pi}{2}}\end{array}$ & $\begin{array}{c}\text { Avoiding overvoltage's; } \\
\text { assuming that the currently } \\
\text { available power at the DC-side is } \\
\text { the same as the injected power } \\
\text { on the AC-side }\end{array}$ \\
\hline [182] & 2019 & $\begin{array}{c}\text { Linear Quadratic Regulator } \\
\text { with added Integral action } \\
\text { (LQRI) with active power filter } \\
\text { (AFP) }\end{array}$ & $\begin{array}{l}\frac{d}{d t} x=[A] x+[B] u+[E] v_{g} \\
u=\left[d_{d}, d_{p}\right]^{T} ; v_{g}=\left[v_{g_{d}}, v_{g_{q}}\right]^{T}\end{array}$ & $\begin{array}{l}\text { fast response, less overshoot and } \\
\text { reduced THD system. }\end{array}$ \\
\hline [183] & 2019 & $\begin{array}{l}\text { Droop Control and Model } \\
\text { predictive control under } \\
\text { different circumstances of } \\
\text { variable load conditions and } \\
\text { fluctuating wind speed }\end{array}$ & $\begin{array}{l}P=\operatorname{Re}\left[V_{g} I_{f}\right]= \\
\frac{3}{2}\left[V_{g_{\alpha}} I_{f_{\alpha}}+V_{g_{\beta}} I_{f_{\beta}}\right] \\
Q=\operatorname{Im}\left[V_{g} I_{f}\right]= \\
\quad \frac{3}{2}\left[V_{g_{\beta}} I_{f_{\alpha}}+V_{g_{\alpha}} I_{f_{\beta}}\right]\end{array}$ & $\begin{array}{l}\text { WT-DG-battery-converter } \\
\text { hybrid energy for domestic load } \\
\text { in Pakistan by handling } \\
\text { intermittent nature of RE } \\
\text { resources, and abrupt } \\
\text { load variations }\end{array}$ \\
\hline
\end{tabular}


Table 8. Inverter control approaches (II).

\begin{tabular}{|c|c|c|c|c|}
\hline Ref. & Year & Power Control & Control Equations & Control Targets \\
\hline [184] & 2019 & $\begin{array}{c}\text { Droop control and } \\
\text { centralized-decentralized } \\
\text { voltage regulation scheme }\end{array}$ & $\begin{array}{c}P_{j}^{P V, h} \in\left[P_{j}^{P V, h, \min }, P_{j}^{P H, h, \max }\right] ; \\
Q_{j}^{P H, h}=\alpha_{j}^{h}+\beta_{j}^{h} \cdot P_{j}^{P V, h}\end{array}$ & $\begin{array}{l}\text { Coordinated Var compensation } \\
\text { for overvoltage mitigation }\end{array}$ \\
\hline [185] & 2019 & $\begin{array}{c}\text { Master-slave or multi-master } \\
\text { topologies, modified vector } \\
\text { control and Intra-phase Power } \\
\text { Management }\end{array}$ & $\begin{array}{c}G(s)=\frac{\omega_{0}-s}{\omega_{0}+s} \\
{\left[\begin{array}{l}d \\
q\end{array}\right]=T\left[\begin{array}{l}\alpha \\
\beta\end{array}\right]} \\
P_{\text {Total }, \phi}=P_{P V}^{\max }+P_{\text {Bat }}^{\max }+P_{\text {Droop }}^{\max }\end{array}$ & $\begin{array}{l}\text { A cooperative control and power } \\
\text { management to ensure that the } \\
\text { loads on all three phases are } \\
\text { supported with as much RES } \\
\text { as possible }\end{array}$ \\
\hline [186] & 2019 & $\begin{array}{l}\text { Self-normalized estimator } \\
\text { (SNE) based algorithm. } \\
\text { PV-BES Microgrid }\end{array}$ & $\begin{array}{l}V_{t}=\left[2\left(V_{s a}^{2}+V_{s b}^{2}+V_{s c}^{2}\right) / 3\right]^{1 / 2} \\
i_{L A}(t)=\sum_{k=1}^{n} i_{L_{a n}} \sin \left[\sigma_{k} \omega t+\lambda_{k}\right]\end{array}$ & $\begin{array}{l}\text { Fluctuations in insolation and } \\
\text { temperature, grid outage } \\
\text { conditions, and load variations } \\
\text { are considered }\end{array}$ \\
\hline [187] & 2019 & $\begin{array}{c}\text { Fuzzy logic and Angle control } \\
\text { by single loop } \\
\text { proportional-integral (PI) }\end{array}$ & $\begin{array}{c}C(s)=K_{p}+\frac{K_{i}}{s} ; \\
K_{p}=\frac{-\omega_{c} \cdot \sin (\theta)}{G\left(j \cdot \omega_{c}\right)} ; K_{i}=\frac{-\omega_{c} \cdot \sin (\theta)}{G\left(j \cdot \omega_{c}\right)}\end{array}$ & $\begin{array}{l}\text { The energy management unit } \\
\text { (EMU) contained a short-term } \\
\text { and a long-term control unit }\end{array}$ \\
\hline [188] & 2019 & $\begin{array}{l}\text { Proportional integral } \\
\text { Controller (PI) and sliding } \\
\text { mode control (SMC) are chosen } \\
\text { to attain the control outputs of } \\
\text { the system }\end{array}$ & $\begin{array}{l}\eta\left(P_{P V}+P_{E S U}\right)+P_{g}=P_{L} \\
I_{E S U}^{r e f}=\frac{1}{V_{E S U}}\left(\frac{P_{L}-P_{g}}{\eta}-P_{P V}\right)\end{array}$ & $\begin{array}{l}\text { Stability and reliability of the } \\
\text { entire system are operating } \\
\text { under various operating modes } \\
\text { and demonstrated through the } \\
\text { laboratory experiments }\end{array}$ \\
\hline [189] & 2019 & Voltage control & $V_{\text {nom }}+\frac{n \cdot(n+1)}{2} \cdot V_{\text {incr }}=V_{\text {limit }}$ & $\begin{array}{l}\text { The impact of } P \text { control (limiting } \\
P \text { to prevent voltage rise) on the } \\
\text { operation and overall generation }\end{array}$ \\
\hline [190] & 2019 & $\begin{array}{l}\text { PV, Plugging Electric Vehicles } \\
\text { and Batteries. Coordinated } \\
\text { control scheme }\end{array}$ & $\begin{array}{c}P_{g, t}-P_{c, t}^{P V}+P_{d, t}^{P V}+P_{c, t}^{P E V}+P_{d, t}^{P E V}- \\
P_{d e f, t}=P_{L, t}^{\omega, t}-P_{P V, t}^{\omega, L}\end{array}$ & $\begin{array}{l}\text { Stochastic dual dynamic } \\
\text { programming (SDDP) algorithm } \\
\text { is then applied to solve the } \\
\text { optimization problem } \\
\text { with uncertainty }\end{array}$ \\
\hline [191] & 2019 & Decoupled Control Strategy & $\begin{array}{l}P_{D C}=V_{D C} C_{d} \frac{d}{d t} V_{D C} \\
\quad P_{A C}=I_{i n, j}^{2} R_{f} \\
\quad V_{D C} C_{d} \frac{d}{d t} V_{D C}=I_{i n, j}^{2} R_{f}\end{array}$ & $\begin{array}{l}\text { Offering conventional power } \\
\text { electronic-based converter } \\
\text { topology, known as Electric } \\
\text { Spring (ES) a decoupled } \\
\text { dual-function capability. } \\
\text { The modified (ES) is able to } \\
\text { achieve PV-grid interface by } \\
\text { injecting the local available PV } \\
\text { power into grid }\end{array}$ \\
\hline
\end{tabular}

\section{Demand-Side Management in Low-Voltage Microgrids}

The appropriately consolidated activity of distributed energy resources and DSM in a microgrid establishes a powerful correspondence plan that can assume a significant part in lessening energy shortcomings by adjusting supply and demand [192]. DSM proceduressuch as flexible load shape, strategic load growth, strategic conservation, flexible load shape, peak clipping, and load shifting [193] - are used to change customer demand profiles in response to emergency conditions or energy market costs [194]. Moreover, DSM offers demand response (DR), which is considered as an alternative solution to the costly investment of upgrading conventional distribution networks [195]. Therefore, the role of DR as a considerable potential for elastic demands in active distribution network management (ADNM) becomes crucial. Based on the control mechanism of the DSM strategy, DSM can be divided into two classes: incentive-based and price-based [196]. Some incentive-based approaches are the following: direct load control (DLC) [197], interruptible/curtailed (I/C) load programs [198], demand bidding/buyback (DB) [199], capacity markets (CM) [200], ancillary service markets (ASM) [201], and emergency demand response (EDR) [202]. For price-based approaches, the following approaches are used: fixed pricing, time-of-Use 
(ToU) [203], dynamic time-of-use (dToU) [204], critical peak pricing (CPP) [205], real-time pricing (RTP) [206], and Vickrey-Clarke-Groves (VCG) [207].

Flexible loads and distributed energy resources can contribute to a distribution network in voltage management. In the decongestion of a distribution network, the management of electrical losses by reducing the distance between loads and source generation increases service reliability [208] and system resilience [209]. Different resources can be also considered as 'flexible loads', such as storage systems, heating, ventilation, and air conditioning (HVAC) systems that are used in residences and businesses [210], water heater systems, refrigeration units, and electric vehicles are also considered 'flexible loads' [211]. Among the different strategies, load shifting is considered the most relevant load management procedure, shifting loads from peak to valley hours, which can be carried out automatically or manually [212]. Loads can be divided into four types [213]: (i) critical loads, being essential to the system and must always be connected to the grid; (ii) controllable loads, which correspond to a flexible demand with variable profiles; (iii) price-sensitive loads, whose demand depends on the price of energy and the hours of connection to the grid; and (iv) thermal loads, related to thermal comfort conditions or boiler control for established conditions. MGs can then reduce the maximum demand values in distribution networks through a coordinated dispatch of generation and demand. Consequently, different DSM strategies are applied to coordinate available renewable resources and demand requirements. This coordination gives those in charge of the distribution network the ability to postpone future expansions within the electrical infrastructure connected to MGs [214].

\section{Discussion}

According to the contributions reviewed in previous sections, we deduce the following points:

- The integration of electrical MGs into LV distribution networks presents a remarkable acceptance among both supply-side and demand-side sectors. Different benefits are identified by end-users, also known as 'prosumers'. Additional benefits are also apparent regarding the environment by reducing fossil fuel dependence and optimizing the use of renewable energy resources. Most LV MG projects integrate a relevant number of PV installations and storage system technologies. However, in turn, these complement other types of distributed generation technologies that could be integrated into the energy supply systems of distribution network users.

- In terms of forecasting approaches, we analyze machine learning, deep learning, and assembly learning solutions. Other methods are based on satellite and numerical predictions, but only minor contributions have currently focused on these methods. Current trends are characterized by the use of machine learning models for both demand and resource forecasting.

- Authors propose different modeling approaches for generation resource or demand forecasting, which means that at least two models are required for an MG. It would be more efficient to propose a single model to forecast both demand and supply-side. Note that such models based on artificial intelligence require a large amount of data for their learning processes. Therefore, it is proposed to evaluate alternative methodologies to achieve more efficient learning processes with reduced data volumes.

- Energy management in MGs also tends to converge on the use of a modern learning tool through programming and the optimal use of energy resources, thus minimizing the use of interconnected networks for energy consumption. Management systems based on known techniques—such as droop control or frequency control—are still being developed to manage resources.

- The results present current trends of residential users as prosumers of small-scale MG integration. It is also possible to integrate multiple prosumers, so-called MG communities or clusters. Note that hybrid MGs and plug-in electric vehicles, as dynamic storage network elements, would allow for integrating these solutions by using V2G technologies. 
- DSM approaches applied to electrical MGs are used as a response strategy to demand profiles, providing a more flexible control focused on the electrical loads of the corresponding MGs. Different studies outline some benefits of DSM control strategies. They propose that different services should be provided by distribution network operators and MG users. When applied to MGs, DSM solutions commonly divide electrical loads into critical, controllable, price-sensitive, and thermally controlled categories. This categorization can optimize the application of DSM in relation to different MG configurations.

- Regarding inverters for MG control, modern power systems often integrate recent technologies into their operations. These solutions include IoT and blockchain, among others. The Multiagent System (MAS) control method [215,216] can respond to current computational challenges through omnipresent, intelligent, autonomous, humanoriented, and supportive attributes. It is based on foundation for intelligent physical agents standards by representing each major autonomous component in the microgrid as an intelligent software agent [217]. Both relevant characteristics and aptitudes improve the extension and flexibility of future power systems by allowing reconfiguration options and the integration of new agent communication technologies. Furthermore, MAS improves robustness and reliability of the system due to the ability to tolerate uncertainties [218], capability to improve the efficiency of computations, and ability to cooperate, negotiate, or compete with other agents at the stage of decision-making processes.

- Nowadays, some protocols explain the issues of electrical MGs. However, there is currently a need to integrate the standards of electronic MGs with standards of distributed generation (DG) in the distribution network levels and with resistance standards. This integration is necessary since the electrical MGs will allow distributed generation to be integrated on a larger scale on the LV distribution network, which will address a transition from passive electrical networks to active distribution networks.

\section{Conclusions and Future Challenges}

This paper reviews current trends in electrical microgrids in Low-Voltage distribution networks. The integration of microgrids has increased considerably due to end-users at distribution networks using Low-Voltage renewable generation as a way to manage their demand and significantly reduce their energy bills. Consequently, the power distribution systems are undergoing a process of transition from passive electrical networks to active networks. This transition requires large investments, which will allow for optimizing the operation of the system (such as reducing energy losses, improving the voltage profile, being a more resilient system) as well as improving reliability through the automation and integration of distributed generation resources and electrical microgrids. Under this framework, it is necessary to discuss in detail how these active elements are changing the way of analyzing, planning, and operating the distribution network market, as well as to evaluate the control strategies and the reliability of these networks. In this paper, the relevance of renewable energy resources and demand forecasting solutions in microgrids connected at Low-Voltage distribution networks are discussed. A balance between generation and demand is necessary to maintain, maximizing energy resources of micro-reservoirs and reducing their consumption from the grid. Forecasting models of renewable resources and demand for end-users provide relevant information, depending on the accuracy of such predictions and the time period being considered. Although there are several forecasting models and proposals in the specific literature, it is still necessary to continue working on these forecasting approaches. Indeed, very short-term prediction models typically focused on $10 \mathrm{~min}$ time intervals should be improved due to the stochastic nature of renewable resources-mainly wind and solar, and their rapid oscillations.

Depending on the type of configuration and distributed generation technology used for integration, microgrids push conventional distribution networks to use integration technologies that allow for energy transitions. Many end-users can become prosumers, 
which affects a distribution network operator's current technical standards and configurations. Additionally, different types of controls need to be explored for application in Low-Voltage microgrids, as do their main characteristics and advantages. Subsequently, this paper highlights the need to propose alternative and more coordinated solutions of microgrids (and clusters of multiple microgrids) in Low-Voltage networks, since the dynamic behavior of end-users of such networks varies over time and produces conditions that microgrids must detect in order to maintain grid reliability and service availability. The implementation of microgrids in distribution networks thus requires more studies focused on innovative systems that allow for increased interaction with future electrical networks. This paper thus encourages the development of alternative coordinated and combined microgrid applications in Low-Voltage networks to enhance grid resilience and flexibility under the current energy transition.

Author Contributions: Conceptualization, M.A.-M.; J.V.; methodology, M.A.-M. writing—original draft preparation, M.A.-M. writing—review and editing, M.A.-M.; J.V.; A.M.-G., D.M.-H.; visualization F.S.; supervision, F.S., A.M.-G. funding acquisition, M.A.-M.; D.M.-H. All authors have read and agreed to the published version of the manuscript.

Funding: This research was funded by FONDOCYT Grant No. 2018-2019-3C1-160 (055-2019 INTEC) in the Dominican Republic.

Data Availability Statement: The data presented in this study are available on request from the corresponding author.

Acknowledgments: The authors gratefully acknowledge the National Background of Innovation and Scientific and Technological Development of the Dominican Republic (FONDOCYT) for the financial support of this research.

Conflicts of Interest: The authors declare no conflict of interest.

\section{Abbreviations}

The following abbreviations are used in this manuscript (by alphabetical order):

$\begin{array}{ll}\text { AC } & \text { Alternating current } \\ \text { CHP } & \text { Combined heat power } \\ \text { DC } & \text { Direct current } \\ \text { DG } & \text { Distributed generation } \\ \text { DSM } & \text { Demand side management } \\ \text { DSO } & \text { Distribution system operator } \\ \text { EMS } & \text { Energy management system } \\ \text { ESS } & \text { Energy store system } \\ \text { GHG } & \text { Greenhouse gas } \\ \text { HVAC } & \text { Heating ventilation and air conditioning } \\ \text { LV } & \text { Low-voltage } \\ \text { MAE } & \text { Mean absolute error } \\ \text { MAPE } & \text { Mean absolute percentage error } \\ \text { MBE } & \text { Mean bias error } \\ \text { MG } & \text { Microgrid } \\ \text { MRE } & \text { Mean relative error } \\ \text { MSE } & \text { Mean square error } \\ \text { PCC } & \text { Point common coupling } \\ \text { PEV } & \text { Plug-in electric vehicles } \\ \text { PV } & \text { Photovoltaic system } \\ \text { P2P } & \text { Peer-to-peer } \\ \text { RMSE } & \text { Root mean squared error } \\ \text { SDG } & \text { Sustainable development goals } \\ \text { STC } & \text { Solar thermal concentrators } \\ \text { TESS } & \text { Thermal energy storage system } \\ \text { WT } & \text { Wind turbine } \\ & \end{array}$




\section{References}

1. Lakshika, K.; Boralessa, M.S.; Perera, M.K.; Wadduwage, D.P.; Saravanan, V.; Hemapala, K.U. Reconfigurable solar photovoltaic systems: A review. Heliyon 2020, 6, e05530. [CrossRef]

2. Bandeiras, F.; Pinheiro, E.; Gomes, M.; Coelho, P.; Fernandes, J. Review of the cooperation and operation of microgrid clusters. Renew. Sustain. Energy Rev. 2020, 133, 110311. [CrossRef]

3. Bukar, A.L.; Tan, C.W.; Yiew, L.K.; Ayop, R.; Tan, W.S. A rule-based energy management scheme for long-term optimal capacity planning of grid-independent microgrid optimized by multi-objective grasshopper optimization algorithm. Energy Convers. Manag. 2020, 221, 113161. [CrossRef] [PubMed]

4. Wang, R.; Lam, C.M.; Hsu, S.C.; Chen, J.H. Life cycle assessment and energy payback time of a standalone hybrid renewable energy commercial microgrid: A case study of Town Island in Hong Kong. Appl. Energy 2019, 250, 760-775. [CrossRef]

5. Burke, M.J.; Stephens, J.C. Political power and renewable energy futures: A critical review. Energy Res. Soc. Sci. 2018, 35, 78-93. [CrossRef]

6. Fontenot, H.; Dong, B. Modeling and control of building-integrated microgrids for optimal energy management-A review. Appl. Energy 2019, 254, 113689. [CrossRef]

7. Chauhan, R.K.; Chauhan, K. Building automation system for grid-connected home to optimize energy consumption and electricity bill. J. Build. Eng. 2019, 21, 409-420. [CrossRef]

8. Fiorini, L.; Aiello, M. Energy management for user's thermal and power needs: A survey. Energy Rep. 2019, 5, 1048-1076. [CrossRef]

9. Chouikhi, S.; Merghem-Boulahia, L.; Esseghir, M. Energy Demand Scheduling Based on Game Theory for Microgrids. In Proceedings of the 2018 IEEE International Conference on Communications (ICC), Kansas City, MO, USA, 20-24 May 2018; pp. 1-6. [CrossRef]

10. Abbas, A.O.; Chowdhury, B.H. Using customer-side resources for market-based transmission and distribution level grid services-A review. Int. J. Electr. Power Energy Syst. 2021, 125, 106480. [CrossRef]

11. Hirsch, A.; Parag, Y.; Guerrero, J. Microgrids: A review of technologies, key drivers, and outstanding issues. Renew. Sustain. Energy Rev. 2018, 90, 402-411. [CrossRef]

12. Bonthu, R.K.; Pham, H.; Aguilera, R.P.; Ha, Q.P. Minimization of building energy cost by optimally managing PV and battery energy storage systems. In Proceedings of the 2017 20th International Conference on Electrical Machines and Systems (ICEMS), Sydney, NSW, Australia, 11-14 August 2017; pp. 1-6. [CrossRef]

13. Chang, H.; Huang, Y.; Ebrahimi, S.; Jatskevich, J. Smart meter based selective harmonics compensation in buildings distribution systems with AC/DC microgrids. In Proceedings of the 2017 IEEE Power \& Energy Society General Meeting, Chicago, IL, USA, 16-20 July 2017; pp. 1-5. [CrossRef]

14. Cotto, S.V.; Lee, W. Microgrid Modular Design for Tribal Healthcare Facilities: Kayenta Health Center PV System Case Study. IEEE Trans. Ind. Appl. 2017, 53, 5121-5129. [CrossRef]

15. Aluisio, B.; Dicorato, M.; Forte, G.; Litrico, G.; Trovato, M. Integration of heat production and thermal comfort models in microgrid operation planning. Sustain. Energy Grids Netw. 2018, 16, 37-54. [CrossRef]

16. Castilla, M.d.M.; Bordons, C. Optimal Management of a Microgrid to Guarantee users' Thermal Comfort. In Proceedings of the 2018 International Conference on Smart Energy Systems and Technologies (SEST), Seville, Spain, 10-12 September 2018; pp. 1-6. [CrossRef]

17. Castillo-Calzadilla, T.; Macarulla, A.M.; Kamara-Esteban, O.; Borges, C.E. Analysis and assessment of an off-grid services building through the usage of a DC photovoltaic microgrid. Sustain. Cities Soc. 2018, 38, 405-419. [CrossRef]

18. Mengelkamp, E.; Gärttner, J.; Rock, K.; Kessler, S.; Orsini, L.; Weinhardt, C. Designing microgrid energy markets: A case study: The Brooklyn Microgrid. Appl. Energy 2018, 210, 870-880. [CrossRef]

19. Guarnieri, M.; Bovo, A.; Giovannelli, A.; Mattavelli, P. A Real Multitechnology Microgrid in Venice: A Design Review. IEEE Ind. Electron. Mag. 2018, 12, 19-31. [CrossRef]

20. Leskarac, D.; Moghimi, M.; Liu, J.; Water, W.; Lu, J.; Stegen, S. Hybrid AC/DC Microgrid testing facility for energy management in commercial buildings. Energy Build. 2018, 174, 563-578. [CrossRef]

21. Bashir, A.A.; Pourakbari-Kasmaei, M.; Contreras, J.; Lehtonen, M. A novel energy scheduling framework for reliable and economic operation of islanded and grid-connected microgrids. Electr. Power Syst. Res. 2019, 171, 85-96. [CrossRef]

22. Moura, P.; Correia, A.; Delgado, J.; Fonseca, P.; Almeida, A.D. University Campus Microgrid for Supporting Sustainable Energy Systems Operation. In Proceedings of the 2020 IEEE/IAS 56th Industrial and Commercial Power Systems Technical Conference (I\&CPS), Las Vegas, NV, USA, 29 June-28 July 2020; pp. 1-7. [CrossRef]

23. Hossain, M.A.; Pota, H.R.; Hossain, M.J.; Blaabjerg, F. Evolution of microgrids with converter-interfaced generations: Challenges and opportunities. Int. J. Electr. Power Energy Syst. 2019, 109, 160-186. [CrossRef]

24. Murray, W.; Adonis, M.; Raji, A. Voltage control in future electrical distribution networks. Renew. Sustain. Energy Rev. 2021, 146, 111100. [CrossRef]

25. Rafi, F.H.M.; Hossain, M.J.; Rahman, M.S.; Taghizadeh, S. An overview of unbalance compensation techniques using power electronic converters for active distribution systems with renewable generation. Renew. Sustain. Energy Rev. 2020, 125, 109812. [CrossRef] 
26. Bahramara, S.; Mazza, A.; Chicco, G.; Shafie-khah, M.; Catalão, J.P.S. Comprehensive review on the decision-making frameworks referring to the distribution network operation problem in the presence of distributed energy resources and microgrids. Int. J. Electr. Power Energy Syst. 2020, 115, 105466. [CrossRef]

27. López-Prado, J.L.; Vélez, J.I.; Garcia-Llinás, G.A. Reliability Evaluation in Distribution Networks with Microgrids: Review and Classification of the Literature. Energies 2020, 13, 6189. [CrossRef]

28. Ghadi, M.J.; Rajabi, A.; Ghavidel, S.; Azizivahed, A.; Li, L.; Zhang, J. From active distribution systems to decentralized microgrids: A review on regulations and planning approaches based on operational factors. Appl. Energy 2019, 253, 113543. [CrossRef]

29. Ali, M.S.; Haque, M.M.; Wolfs, P. A review of topological ordering based voltage rise mitigation methods for LV distribution networks with high levels of photovoltaic penetration. Renew. Sustain. Energy Rev. 2019, 103, 463-476. [CrossRef]

30. Alotaibi, I.; Abido, M.A.; Khalid, M.; Savkin, A.V. A Comprehensive Review of Recent Advances in Smart Grids: A Sustainable Future with Renewable Energy Resources. Energies 2020, 13, 6269. [CrossRef]

31. Roslan, M.F.; Hannan, M.A.; Ker, P.J.; Uddin, M.N. Microgrid control methods toward achieving sustainable energy management. Appl. Energy 2019, 240, 583-607. [CrossRef]

32. Xu, Z.; Yang, P.; Zheng, C.; Zhang, Y.; Peng, J.; Zeng, Z. Analysis on the organization and Development of multi-microgrids. Renew. Sustain. Energy Rev. 2018, 81, 2204-2216. [CrossRef]

33. Hannan, M.; Tan, S.Y.; Al-Shetwi, A.Q.; Jern, K.P.; Begum, R. Optimized controller for renewable energy sources integration into microgrid: Functions, constraints and suggestions. J. Clean. Prod. 2020, 256, 120419. [CrossRef]

34. Afrin, N.; Yang, F.; Lu, J. Voltage support strategy for PV inverter to enhance dynamic voltage stability of islanded microgrid. Int. J. Electr. Power Energy Syst. 2020, 121, 106059. [CrossRef]

35. Mathew, P.; Madichetty, S.; Mishra, S. A Multi-Level Control and Optimization Scheme for Islanded PV Based Microgrid: A Control Frame Work. IEEE J. Photovoltaics 2019, 9, 822-831. [CrossRef]

36. Flammini, M.G.; Prettico, G.; Fulli, G.; Bompard, E.; Chicco, G. Interaction of consumers, photovoltaic systems and electric vehicle energy demand in a Reference Network Model. In Proceedings of the 2017 International Conference of Electrical and Electronic Technologies for Automotive, Turin, Italy, 15-16 June 2017; pp. 1-5. [CrossRef]

37. AbuElrub, A.; Hamed, F.; Saadeh, O. Microgrid integrated electric vehicle charging algorithm with photovoltaic generation. J. Energy Storage 2020, 32, 101858. [CrossRef]

38. Hajiaghasi, S.; Salemnia, A.; Hamzeh, M. Hybrid energy storage system for microgrids applications: A review. J. Energy Storage 2019, 21, 543-570. [CrossRef]

39. Adinolfi, F.; D’Agostino, F.; Massucco, S.; Saviozzi, M.; Silvestro, F. Advanced operational functionalities for a low voltage Microgrid test site. In Proceedings of the 2015 IEEE Power Energy Society General Meeting, Denver, CO, USA, 26-30 July 2015; pp. 1-5. [CrossRef]

40. Mahdavi Tabatabaei, N.; Kabalci, E.; Bizon, N. (Eds.) Overview of Microgrid. In Microgrid Architectures, Control and Protection Methods; Springer International Publishing: Cham, Switzerland, 2020; pp. 3-19._1. [CrossRef]

41. Zhou, B.; Zou, J.; Chung, C.Y.; Wang, H.; Liu, N.; Voropai, N.; Xu, D. Multi-microgrid Energy Management Systems: Architecture, Communication, and Scheduling Strategies. J. Mod. Power Syst. Clean Energy 2021, 9, 463-476. [CrossRef]

42. Rebollal, D.; Carpintero-Rentería, M.; Santos-Martín, D.; Chinchilla, M. Microgrid and Distributed Energy Resources Standards and Guidelines Review: Grid Connection and Operation Technical Requirements. Energies 2021, 14, 523. [CrossRef]

43. Mejía, M.A.; Martijena, A.A.; Ruíz, A.A.C.; Arias, Á.I.R.; Cuello, E.B.; Maimó, J.G.; Mariano-Hernández, D. Protocolos y topologías utilizadas en los sistemas de comunicación de las microrredes eléctricas. Cienc. Ing. Y Apl. 2021, 4, 81-95. [CrossRef]

44. Du, Y.; Wang, Z.; Liu, G.; Chen, X.; Yuan, H.; Wei, Y.; Li, F. A cooperative game approach for coordinating multi-microgrid operation within distribution systems. Appl. Energy 2018, 222, 383-395. [CrossRef]

45. Lehtonen, M. Flexible operation of grid-connected microgrid using ES. IET Gener. Transm. Distrib. 2020, 14, 254-264.

46. Liu, M.; Zhao, C.; Deng, R.; Cheng, P.; Wang, W.; Chen, J. False Data Injection Attacks and Countermeasures in Smart Microgrid Systems; Elsevier Inc.: Amsterdam, The Netherlands, 2020; pp. 263-279. [CrossRef]

47. Hamzeh Aghdam, F.; Salehi, J.; Ghaemi, S. Contingency based energy management of multi-microgrid based distribution network. Sustain. Cities Soc. 2018, 41, 265-274. [CrossRef]

48. Kavousi-Fard, A.; Zare, A.; Khodaei, A. Effective Dynamic Scheduling of Reconfigurable Microgrids. IEEE Trans. Power Syst. 2018, 33, 5519-5530. [CrossRef]

49. Gao, J.; Chen, J.J.; Cai, Y.; Zeng, S.Q.; Peng, K. A two-stage Microgrid cost optimization considering distribution network loss and voltage deviation. Energy Rep. 2020, 6, 263-267. [CrossRef]

50. Ahmad, F.; Rasool, A.; Ozsoy, E.; Sekar, R.; Sabanovic, A.; Elitaş, M. Distribution system state estimation-A step towards smart grid. Renew. Sustain. Energy Rev. 2018, 81, 2659-2671. [CrossRef]

51. Khederzadeh, M.; Zandi, S. Enhancement of Distribution System Restoration Capability in Single/Multiple Faults by Using Microgrids as a Resiliency Resource. IEEE Syst. J. 2019, 13, 1796-1803. [CrossRef]

52. Shamshirband, M.; Salehi, J.; Gazijahani, F.S. Decentralized trading of plug-in electric vehicle aggregation agents for optimal energy management of smart renewable penetrated microgrids with the aim of CO2 emission reduction. J. Clean. Prod. 2018, 200, 622-640. [CrossRef] 
53. Liu, Z.; Yang, J.; Zhang, Y.; Ji, T.; Zhou, J.; Cai, Z. Multi-Objective Coordinated Planning of Active-Reactive Power Resources for Decentralized Droop-Controlled Islanded Microgrids Based on Probabilistic Load Flow. IEEE Access 2018, 6, 40267-40280. [CrossRef]

54. Li, Y.; Fan, X.; Cai, Z.; Yu, B. Optimal active power dispatching of microgrid and distribution network based on model predictive control. Tsinghua Sci. Technol. 2018, 23, 266-276. [CrossRef]

55. Wang, X.; Wang, C.; Xu, T.; Guo, L.; Li, P.; Yu, L.; Meng, H. Optimal voltage regulation for distribution networks with multi-microgrids. Appl. Energy 2018, 210, 1027-1036. [CrossRef]

56. Warsi, N.A.; Siddiqui, A.S.; Kirmani, S.; Sarwar, M. Impact Assessment of Microgrid in Smart Cities: Indian Perspective. Technol. Econ. Smart Grids Sustain. Energy 2019, 4, 14. [CrossRef]

57. Choudhury, S. A comprehensive review on issues, investigations, control and protection trends, technical challenges and future directions for Microgrid technology. Int. Trans. Electr. Energy Syst. 2020, 30, e12446. [CrossRef]

58. Gilani, M.A.; Kazemi, A.; Ghasemi, M. Distribution system resilience enhancement by microgrid formation considering distributed energy resources. Energy 2020, 191, 116442. [CrossRef]

59. Ajoulabadi, A.; Ravadanegh, S.N.; Mohammadi-Ivatloo, B. Flexible scheduling of reconfigurable microgrid-based distribution networks considering demand response program. Energy 2020, 196, 117024. [CrossRef]

60. Mejia, M.E.A.; Mariano-Hernandez, D.; Santana, R.B.; de Leon Concepcion, E.; Martijena, A.A.; Ruiz, A.C.; Mendoza, D.L.; Suero, E.C.F. Design of an Interconnected Microgrid for the Electrification of San Pablo II Community: Case of Study Dominican Republic. In Proceedings of the 2020 IEEE International Smart Cities Conference (ISC2), Piscataway, NJ, USA, 28 September-1 October 2020. [CrossRef]

61. Balint, R.; Fodor, A.; Magyar, A.; Bálint, R.; Fodor, A.; Magyar, A. Model-based power generation estimation of solar panels using weather forecast for microgrid application. Acta Polytech. Hung. 2019, 16, 149-165. [CrossRef]

62. Mele, E.; Elias, C.; Ktena, A. Electricity use profiling and forecasting at microgrid level. In Proceedings of the 2018 IEEE 59th International Scientific Conference on Power and Electrical Engineering of Riga Technical University (RTUCON), Riga, Latvia, 12-13 November 2018. [CrossRef]

63. Semero, Y.K.; Zhang, J.; Zheng, D.; Wei, D. An Accurate Very Short-Term Electric Load Forecasting Model with Binary Genetic Algorithm Based Feature Selection for Microgrid Applications. Electr. Power Components Syst. 2018, 46, 1570-1579. [CrossRef]

64. Duverger, E.; Penin, C.; Alexandre, P.; Thiery, F.; Gachon, D.; Talbert, T. Irradiance forecasting for microgrid energy management. In Proceedings of the 2017 IEEE PES Innovative Smart Grid Technologies Conference Europe (ISGT-Europe), Turin, Italy, 26-29 September 2017; pp. 1-6. [CrossRef]

65. Dutta, S.; Li, Y.; Venkataraman, A.; Costa, L.M.; Jiang, T.; Plana, R.; Tordjman, P.; Choo, F.H.; Foo, C.F.; Puttgen, H.B. Load and Renewable Energy Forecasting for a Microgrid using Persistence Technique. Energy Procedia 2017, 143, 617-622. [CrossRef]

66. Sabzehgar, R.; Amirhosseini, D.Z.; Rasouli, M. Solar power forecast for a residential smart microgrid based on numerical weather predictions using artificial intelligence methods. J. Build. Eng. 2020, 32, 101629. [CrossRef]

67. Izzatillaev, J.; Yusupov, Z. Short-term Load Forecasting in Grid-connected Microgrid. In Proceedings of the 2019 7th International Istanbul Smart Grids and Cities Congress and Fair (ICSG), Istanbul, Turkey, 25-26 April 2019; pp. 71-75. [CrossRef]

68. Alavi, S.A.; Mehran, K.; Vahidinasab, V.; Catalao, J.P. Forecast Based Consensus Control for DC Microgrids Using Distributed Long Short-Term Memory Deep Learning Models. IEEE Trans. Smart Grid 2021, 12, 3718-3730. [CrossRef]

69. Moradzadeh, A.; Zakeri, S.; Shoaran, M.; Mohammadi-Ivatloo, B.; Mohammadi, F. Short-Term Load Forecasting of Microgrid via Hybrid Support Vector Regression and Long Short-Term Memory Algorithms. Sustainability 2020, 12, 7076. [CrossRef]

70. Genikomsakis, K.; Lopez, S.; Dallas, P.; Ioakimidis, C. Simulation of Wind-Battery Microgrid Based on Short-Term Wind Power Forecasting. Appl. Sci. 2017, 7, 1142. [CrossRef]

71. Agüera-Pérez, A.; Palomares-Salas, J.C.; González de la Rosa, J.J.; Florencias-Oliveros, O. Weather forecasts for microgrid energy management: Review, discussion and recommendations. Appl. Energy 2018, 228, 265-278. [CrossRef]

72. Bueso, M.C.; Paredes-Parra, J.M.; Mateo-Aroca, A.; Molina-García, A. A Characterization of Metrics for Comparing Satellite-Based and Ground-Measured Global Horizontal Irradiance Data: A Principal Component Analysis Application. Sustainability 2020, 12, 2454. [CrossRef]

73. Mbuya, B.; Moncecchi, M.; Merlo, M.; Kivevele, T. Short-term load forecasting in a hybrid microgrid: A case study in Tanzania. J. Electr. Syst. 2019, 15, 593-606.

74. Mele, E.; Elias, C.; Ktena, A. Machine Learning Platform for Profiling and Forecasting at Microgrid Level. Electr. Control Commun. Eng. 2019, 15, 21-29. [CrossRef]

75. Nespoli, A.; Mussetta, M.; Ogliari, E.; Leva, S.; Fernández-Ramírez, L.; García-Triviño, P. Robust 24 Hours ahead Forecast in a Microgrid: A Real Case Study. Electronics 2019, 8, 1434. [CrossRef]

76. Rodríguez, F.; Fleetwood, A.; Galarza, A.; Fontán, L. Predicting solar energy generation through artificial neural networks using weather forecasts for microgrid control. Renew. Energy 2018, 126, 855-864. [CrossRef]

77. Rodríguez, F.; Florez-Tapia, A.M.; Fontán, L.; Galarza, A. Very short-term wind power density forecasting through artificial neural networks for microgrid control. Renew. Energy 2020, 145, 1517-1527. [CrossRef]

78. Sujil, A.; Kumar, R.; Bansal, R.C. FCM Clustering-ANFIS-based PV and wind generation forecasting agent for energy management in a smart microgrid. J. Eng. 2019, 2019, 4852-4857. [CrossRef] 
79. Yuan, Y.; Tang, J. On Advanced Control Methods toward Power Capture and Load Mitigation in Wind Turbines. Engineering 2017, 3, 494-503. [CrossRef]

80. Alhussein, M.; Haider, S.I.; Aurangzeb, K. Microgrid-Level Energy Management Approach Based on Short-Term Forecasting of Wind Speed and Solar Irradiance. Energies 2019, 12, 1487. [CrossRef]

81. Arkhangelski, J.; Mahamadou, A.T.; Lefebvre, G. Data forecasting for Optimized Urban Microgrid Energy Management. In Proceedings of the 2019 IEEE International Conference on Environment and Electrical Engineering and 2019 IEEE Industrial and Commercial Power Systems Europe (EEEIC/I\&CPS Europe), Genova, Italy, 11-14 June 2019. [CrossRef]

82. Faraji, J.; Hashemi-Dezaki, H.; Ketabi, A. Multi-year load growth-based optimal planning of grid-connected microgrid considering long-term load demand forecasting: A case study of Tehran, Iran. Sustain. Energy Technol. Assessments 2020, 42, 100827. [CrossRef]

83. Husein, M.; Chung, I.Y. Impact of Solar Power and Load Demand Forecast Uncertainty on the Optimal Operation of Microgrid. In Proceedings of the 2019 IEEE PES/IAS PowerAfrica, Abuja, Nigeria, 20-23 August 2019; pp. 199-203. [CrossRef]

84. Moradzadeh, A.; Moayyed, H.; Zakeri, S.; Mohammadi-Ivatloo, B.; Aguiar, A.P. Deep Learning-Assisted Short-Term Load Forecasting for Sustainable Management of Energy in Microgrid. Inventions 2021, 6, 15. [CrossRef]

85. Shakir, M.; Biletskiy, Y. Forecasting and optimisation for microgrid in home energy management systems. IET Gener. Transm. Distrib. 2020, 14, 3458-3468. [CrossRef]

86. Wen, L.; Zhou, K.; Yang, S.; Lu, X. Optimal load dispatch of community microgrid with deep learning based solar power and load forecasting. Energy 2019, 171, 1053-1065. [CrossRef]

87. Husein, M.; Chung, I.Y. Day-Ahead Solar Irradiance Forecasting for Microgrids Using a Long Short-Term Memory Recurrent Neural Network: A Deep Learning Approach. Energies 2019, 12, 1856. [CrossRef]

88. Tan, M.; Jin, J.C.; Su, Y.X. An Ensemble Learning Approach for Short-Term Load Forecasting of Grid-Connected Multi-energy Microgrid. In Proceedings of the 2019 IEEE Symposium Series on Computational Intelligence (SSCI), Xiamen, China, 6-9 December 2019; pp. 497-502. [CrossRef]

89. Polimeni, S.; Nespoli, A.; Leva, S.; Valenti, G.; Manzolini, G. Implementation of Different PV Forecast Approaches in a MultiGood MicroGrid: Modeling and Experimental Results. Processes 2021, 9, 323. [CrossRef]

90. Samadi, E.; Badri, A.; Ebrahimpour, R. Decentralized multi-agent based energy management of microgrid using reinforcement learning. Int. J. Electr. Power Energy Syst. 2020, 122, 106211. [CrossRef]

91. Butturi, M.A.; Lolli, F.; Sellitto, M.A.; Balugani, E.; Gamberini, R.; Rimini, B. Renewable energy in eco-industrial parks and urban-industrial symbiosis: A literature review and a conceptual synthesis. Appl. Energy 2019, 255, 113825. [CrossRef]

92. Ferro, G.; Laureri, F.; Minciardi, R.; Robba, M. An optimization model for electrical vehicles scheduling in a smart grid. Sustain. Energy Grids Netw. 2018, 14, 62-70. [CrossRef]

93. Mosa, M.A.; Ali, A.A. Energy management system of low voltage dc microgrid using mixed-integer nonlinear programing and a global optimization technique. Electr. Power Syst. Res. 2021, 192, 106971. [CrossRef]

94. Harmouch, F.Z.; Krami, N.; Hmina, N. A multiagent based decentralized energy management system for power exchange minimization in microgrid cluster. Sustain. Cities Soc. 2018, 40, 416-427. [CrossRef]

95. Kumar, R.S.; Raghav, L.P.; Raju, D.K.; Singh, A.R. Intelligent demand side management for optimal energy scheduling of grid connected microgrids. Appl. Energy 2021, 285, 116435. [CrossRef]

96. Magnani, S.; Danti, P.; Cauchi, G. Experimental results of the optimized management of an EMS-equipped small-size prosumer. Energy Procedia 2018, 148, 679-686. [CrossRef]

97. Melhem, F.Y.; Grunder, O.; Hammoudan, Z.; Moubayed, N. Energy Management in Electrical Smart Grid Environment Using Robust Optimization Algorithm. IEEE Trans. Ind. Appl. 2018, 54, 2714-2726. [CrossRef]

98. Wang, J.; Zhao, C.; Pratt, A.; Baggu, M. Design of an advanced energy management system for microgrid control using a state machine. Appl. Energy 2018, 228, 2407-2421. [CrossRef]

99. Hu, J.; Shan, Y.; Xu, Y.; Guerrero, J.M. A coordinated control of hybrid ac/dc microgrids with PV-wind-battery under variable generation and load conditions. Int. J. Electr. Power Energy Syst. 2019, 104, 583-592. [CrossRef]

100. Leonori, S.; Martino, A.; Mascioli, F.M.F.; Rizzi, A. ANFIS Microgrid Energy Management System Synthesis by Hyperplane Clustering Supported by Neurofuzzy Min-Max Classifier. IEEE Trans. Emerg. Top. Comput. Intell. 2019, 3, 193-204. [CrossRef]

101. Nayak, C.K.; Kasturi, K.; Nayak, M.R. Economical management of microgrid for optimal participation in electricity market. J. Energy Storage 2019, 21, 657-664. [CrossRef]

102. Nge, C.L.; Ranaweera, I.U.; Midtgård, O.M.; Norum, L. A real-time energy management system for smart grid integrated photovoltaic generation with battery storage. Renew. Energy 2019, 130, 774-785. [CrossRef]

103. Sedighizadeh, M.; Esmaili, M.; Jamshidi, A.; Ghaderi, M.H. Stochastic multi-objective economic-environmental energy and reserve scheduling of microgrids considering battery energy storage system. Int. J. Electr. Power Energy Syst. 2019, 106, 1-16. [CrossRef]

104. Afrakhte, H.; Bayat, P. A self-evolving type-2 fuzzy energy management strategy for multi-microgrid systems. Comput. Electr. Eng. 2020, 85, 106702. [CrossRef]

105. Leonori, S.; Martino, A.; Frattale Mascioli, F.M.; Rizzi, A. Microgrid Energy Management Systems Design by Computational Intelligence Techniques. Appl. Energy 2020, 277, 115524. [CrossRef]

106. Alkatheiri, M.S.; Alqarni, M.A.; Chauhdary, S.H. Cyber security framework for smart home energy management systems. Sustain. Energy Technol. Assessments 2021, 46, 101232. [CrossRef] 
107. Arcos-Aviles, D.; Pascual, J.; Guinjoan, F.; Marroyo, L.; García-Gutiérrez, G.; Gordillo-Orquera, R.; Llanos-Proaño, J.; Sanchis, P.; Motoasca, T.E. An Energy Management System Design Using Fuzzy Logic Control: Smoothing the Grid Power Profile of a Residential Electro-Thermal Microgrid. IEEE Access 2021, 9, 25172-25188. [CrossRef]

108. Bagheri Sanjareh, M.; Nazari, M.H.; Gharehpetian, G.B.; Hosseinian, S.H. A novel approach for sizing thermal and electrical energy storage systems for energy management of islanded residential microgrid. Energy Build. 2021, 238, 110850. [CrossRef]

109. Farzaneh, H.; Shokri, M.; Kebriaei, H.; Aminifar, F. Robust Energy Management of Residential Nanogrids via Decentralized Mean Field Control. IEEE Trans. Sustain. Energy 2020, 11, 1995-2002. [CrossRef]

110. Sekar, R.; Suresh, D.S.; Naganagouda, H. A review on power electronic converters suitable for renewable energy sources. In Proceedings of the 2017 International Conference on Electrical, Electronics, Communication, Computer, and Optimization Techniques (ICEECCOT), Mysuru, India, 15-16 December 2017; pp. 501-506. [CrossRef]

111. Gao, D.Z.; Sun, K. Chapter 16-DC-AC Inverters. In Electric Renewable Energy Systems; Muhammad, H.R., Ed.; Academic Press: Boston, MA, USA, 2016; pp. 354-381. ISBN 978-012804448-3.

112. Karimi, A.; Khayat, Y.; Naderi, M.; Dragičević, T.; Mirzaei, R.; Blaabjerg, F.; Bevrani, H. Inertia Response Improvement in AC Microgrids: A Fuzzy-Based Virtual Synchronous Generator Control. IEEE Trans. Power Electron. 2020, 35, 4321-4331. [CrossRef]

113. Yap, K.Y.; Sarimuthu, C.R.; Lim, J.M.Y. Virtual Inertia-Based Inverters for Mitigating Frequency Instability in Grid-Connected Renewable Energy System: A Review. Appl. Sci. 2019, 9, 5300. [CrossRef]

114. Michael, N.E.; Hasan, S.; Mishra, S. Virtual inertia provision through data centre and electric vehicle for ancillary services support in microgrid. IET Renew. Power Gener. 2020, 14, 3792-3801. [CrossRef]

115. Pattabiraman, D.; Lasseter, R.H.; Jahns, T.M. Comparison of Grid Following and Grid Forming Control for a High Inverter Penetration Power System. In Proceedings of the 2018 IEEE Power \& Energy Society General Meeting (PESGM), Portland, OR, USA, 5-10 August 2018; pp. 1-5. [CrossRef]

116. Abbasi, M.; Hedayatpour, M.; Garganeev, A.G. Microgrid Voltage and Frequency Control Using Droop Control Based on Master/Slave Method. In Proceedings of the 2020 21st International Conference of Young Specialists on Micro/Nanotechnologies and Electron Devices (EDM), Chemal, Russia, 29 June-3 July 2020; pp. 367-373.

117. Khan, M.W.; Wang, J.; Ma, M.; Xiong, L.; Li, P.; Wu, F. Optimal energy management and control aspects of distributed microgrid using multi-agent systems. Sustain. Cities Soc. 2018, 44, 855-870. [CrossRef]

118. Andishgar, M.H.; Gholipour, E.; allah Hooshmand, R. An overview of control approaches of inverter-based microgrids in islanding mode of operation. Renew. Sustain. Energy Rev. 2017, 80, 1043-1060. [CrossRef]

119. Alfergani, A.; Alfaitori, K.A.; Khalil, A.; Buaossa, N. Control Strategies in AC Microgrid: A Brief Review. In Proceedings of the 2018 9th International Renewable Energy Congress (IREC), Hammamet, Tunisia, 20-22 March 2018.

120. Bayhan, S.; Abu-rub, H. Model Predictive Droop Control of Distributed Generation Inverters in Islanded AC Microgrid. In Proceedings of the 2017 11th IEEE International Conference on Compatibility, Power Electronics and Power Engineering (CPE-POWERENG), Cadiz, Spain, 4-6 April 2017; pp. 247-252.

121. Kalke, D.; Suryawanshi, H.M.; Talapur, G.G. Modified Droop and Master-Slave Control for Load Sharing in Multiple Standalone AC Microgrids. IEEE Ind. Electron. Soc. 2019, 1, 1862-1867.

122. Savaghebi, M.; Member, S.; Jalilian, A.; Vasquez, J.C.; Guerrero, J.M. Autonomous Voltage Unbalance Compensation in an Islanded Droop-Controlled Microgrid. IEEE Trans. Ind. Electron. 2011, 60, 1390-1402. [CrossRef]

123. Shi, H.; Zhuo, F.; Geng, Z. A Unify Unbalance Compensation Strategy for Islanded Microgrid with Unbalanced Condition. In Proceedings of the 2015 9th International Conference on Power Electronics and ECCE Asia (ICPE-ECCE Asia), Seoul, Korea, 1-5 June 2015; pp. 2814-2819.

124. Hu, Y.; Xiang, J.; Peng, Y.; Yang, P.; Wei, W. Decentralised control for reactive power sharing using adaptive virtual impedance. IET Gener. Transm. Distrib. 2018, 12, 1198-1205. [CrossRef]

125. Bintoudi, A.D.; Zyglakis, L.; Apostolos, T.; Ioannidis, D.; Al-agtash, S.; Jose, L.; Onen, A.; Azzopardi, B.; Hadjidemetriou, L.; Martensen, N. Novel Hybrid Design for Microgrid Control. In Proceedings of the 2017 IEEE PES Asia-Pacific Power and Energy Engineering Conference (APPEEC), Bangalore, India, 8-10 November 2017.

126. Mahdavyfakhr, M.; Dadjo Tavakoli, S.; Safdarzadeh, O.; Hamzeh, M. A robust active damping method to improve the parallel operation of micro-inverters in islanded microgrids. In Proceedings of the 2017 8th Power Electronics, Drive Systems \& Technologies Conference (PEDSTC), Mashhad, Iran, 14-16 February 2017; pp. 108-113. [CrossRef]

127. Yang, J.; Yuan, W.; Sun, Y.; Han, H.; Hou, X.; Guerrero, J.M. Electrical Power and Energy Systems A novel quasi-master-slave control frame for PV-storage independent microgrid. Electr. Power Energy Syst. 2018, 97, 262-274. [CrossRef]

128. Tang, X.; Deng, W.; Qi, Z. Investigation of the Dynamic Stability of Microgrid. IEEE Trans. Power Syst. 2014, 29, 698-706. [CrossRef]

129. Ghosh, S. Correction of Line-voltage Unbalance by the Decentralized Inverters in an Islanded Microgrid. In Proceedings of the 2020 IEEE Applied Power Electronics Conference and Exposition (APEC), New Orleans, LA, USA, 15-19 March 2020; pp. 622-628.

130. Hasan, M.A. Microgrid architecture, control, and operation. In Hybrid-Renewable Energy Systems in Microgrids; Woodhead Publishing: Sawston, UK, 2018. [CrossRef]

131. Rajesh, K.S.; Dash, S.S.; Rajagopal, R.; Sridhar, R. A review on control of ac microgrid. Renew. Sustain. Energy Rev. 2017, 71, 814-819. [CrossRef] 
132. Fernández-Guillamón, A.; Gómez-Lázaro, E.; Muljadi, E.; Molina-García, Á. Power systems with high renewable energy sources: A review of inertia and frequency control strategies over time. Renew. Sustain. Energy Rev. 2019, 115, 109369. [CrossRef]

133. Vandoorn, T.L.; De Kooning, J.D.; Meersman, B.; Guerrero, J.M.; Vandevelde, L. Automatic power-sharing modification of P/V droop controllers in low-voltage resistive microgrids. IEEE Trans. Power Deliv. 2012, 27, 2318-2325. [CrossRef]

134. Azim, M.I.; Hossain, M.A.; Mohiuddin, S.M.; Hossain, M.J.; Pota, H.R. Proportional reactive power sharing for islanded microgrids. In Proceedings of the 2016 IEEE 11th Conference on Industrial Electronics and Applications, ICIEA 2016, Hefei, China, 5-7 June 2016; pp. 1139-1144. [CrossRef]

135. Cagnano, A.; Tuglie, E.D.; Cervi, A.; Stecca, R.; Turri, R.; Vian, A. Re- ynchronization control strategy for master - slave controlled microgrids. In Proceedings of the 2019 1st International Conference on Energy Transition in the Mediterranean Area (SyNERGY MED), Cagliari, Italy, 28-30 May 2019; pp. 1-6.

136. Peyghami, S.; Mokhtari, H.; Blaabjerg, F. Hierarchical Power Sharing Control in DC Microgrids; Elsevier Inc.: Amsterdam, The Netherlands, 2017; pp. 63-100. [CrossRef]

137. Cagnano, A.; De Tuglie, E.; Mancarella, P. Microgrids: Overview and guidelines for practical implementations and operation. Appl. Energy 2020, 258, 114039. [CrossRef]

138. Yassuda, D.; Vechiu, I.; Gaubert, J.P. A review of hierarchical control for building microgrids. Renew. Sustain. Energy Rev. 2020, 118, 109523. [CrossRef]

139. Hedayatpour, M.; Mirzaei, A. Control Methods in Microgrids (Chapter). December 2018. Available online: https://www. researchgate.net/publication/330002459_Control_Methods_in_Microgrids (accessed on 19 July 2021).

140. Zhang, H.; Zhou, J.; Sun, Q.; Guerrero, J.M.; Ma, D. Data-Driven Control for Interlinked AC/DC Microgrids Via Model-Free Adaptive Control and Dual-Droop Control. IEEE Trans. Smart Grid 2017, 8, 557-571. [CrossRef]

141. Rosini, A.; Mestriner, D.; Labella, A.; Bonfiglio, A.; Procopio, R. A decentralized approach for frequency and voltage regulation in islanded PV-Storage microgrids. Electr. Power Syst. Res. 2021, 193, 106974. [CrossRef]

142. Tucci, M.; Meng, L.; Guerrero, J.M.; Ferrari-Trecate, G. Stable current sharing and voltage balancing in DC microgrids: A consensus-based secondary control layer. Automatica 2018, 95, 1-13. [CrossRef]

143. Cai, N.; Mitra, J. A multi-level control architecture for master-slave organized microgrids with power electronic interfaces. Electr. Power Syst. Res. 2014, 109, 8-19. [CrossRef]

144. Ding, T.; Lin, Y.; Bie, Z.; Chen, C. A resilient microgrid formation strategy for load restoration considering master-slave distributed generators and topology reconfiguration. Appl. Energy 2017, 199, 205-216. [CrossRef]

145. Chengshan, W.; Xialin, L.I.; Li, G.U.O.; Yunwei, L.I. A seamless operation mode transition control strategy for a microgrid based on master-slave control. Sci. China Technol. Sci. 2012, 55, 1644-1654. [CrossRef]

146. Zhao, H.; Yang, Q.; Zeng, H. Multi-loop Virtual Synchronous Generator Control of Inverter-based DGs under Microgrid Dynamics. Gener. Transm. Distrib. 2017, 11, 795-803. [CrossRef]

147. Hassan Bevrani, S.S. An Intelligent Droop Control for Simultaneous Voltage and Frequency Regulation in Islanded Microgrids. IEEE Trans. Smart Grid 2013, 4, 1505-1513. [CrossRef]

148. Adachi, R.; Yamashita, Y.; Kobayashi, K. Data aggregation based estimation for sensor network with communication delay. IFAC-PapersOnLine 2017, 50, 2488-2493. [CrossRef]

149. Caldognetto, T.; Tenti, P. Microgrids operation based on master-slave cooperative control. IEEE J. Emerg. Sel. Top. Power Electron. 2014, 2, 1081-1088. [CrossRef]

150. Trip, S.; Cucuzzella, M.; Cheng, X.; Scherpen, J. Distributed Averaging Control for Voltage Regulation and Current Sharing in DC Microgrids. IEEE Control Syst. Lett. 2018, 3, 174-179. [CrossRef]

151. Han, R.; Meng, L.; Guerrero, J.M.; Vasquez, J.C. Distributed non- linear control with event-triggered communication to achieve current- sharing and voltage regulation in dc microgrids. IEEE Trans. Power Electron. 2018, 33, 6416-6433. [CrossRef]

152. Zha, D.; Wang, Q.; Cheng, M.; Deng, F.; Buja, G. Distributed cooperative control for multiple dc electric springs with novel topologies applied in DC microgrid. In Proceedings of the PEDG 2019-2019 IEEE 10th International Symposium on Power Electronics for Distributed Generation Systems, Xi'an, China, 3-6 June 2019; pp. 648-652. [CrossRef]

153. Nasirian, V.; Moayedi, S.; Davoudi, A.; Lewis, F.L. Distributed cooperative control of dc microgrids. IEEE Trans. Power Electron. 2015, 30, 2288-2303. [CrossRef]

154. De Persis, C.; Weitenberg, E.; Dörfler, F. A power consensus algorithm for DC microgrids. IFAC-PapersOnLine 2017, 50, 10009-10014. [CrossRef]

155. Cucuzzella, S.M.; Trip, C.; De Persis, X.; Cheng, A.F.; van der Schaft, A. A Robust Consensus Algorithm for Current Sharing and Voltage Regulation in DC Microgrids. IEEE Trans. Control. Syst. Technol. 2019, 27, 1583-1595. [CrossRef]

156. Sun, X.; Lee, Y.-S.; Dehong, X. Modeling, analysis, and imple- mentation of parallel multi-inverter systems with instantaneous average- current-sharing scheme. IEEE Trans. Power Electron. 2003, 18, 844-856.

157. Khadkikar, P.S.V. A New Virtual Harmonic Impedance Scheme for Harmonic Power Sharing in an Islanded. IEEE Trans. Power Deliv. 2016, 31, 936-945.

158. John, B.; Ghosh, A.; Zare, F. Load sharing in medium voltage islanded microgrids with advanced angle droop control. IEEE Trans. Smart Grid 2018, 9, 6461-6469. [CrossRef]

159. Moussa, H.; Shahin, A.; Martin, J.P.; Pierfederici, S.; Moubayed, N. Optimal angle droop for power sharing enhancement with stability improvement in islanded microgrids. IEEE Trans. Smart Grid 2018, 9, 5014-5026. [CrossRef] 
160. Bendib, A.; Kara, K. Droop Controller Based Primary Control Scheme for Parallel-Connected Single-Phase Inverters in Islanded AC Microgrid. In Proceedings of the 2017 5th International Conference on Electrical Engineering-Boumerdes (ICEE-B), Boumerdes, Algeria, 29-31 October 2017.

161. Kolluri, R.R.; Mareels, I.; Alpcan, T.; Brazil, M.; De Hoog, J.; Thomas, D.A. Power sharing in angle droop controlled microgrids. IEEE Trans. Power Syst. 2017, 32, 4743-4751. [CrossRef]

162. Hassan, M.A. Dynamic Stability of an Autonomous Microgrid Considering Active Load Impact with New Dedicated Synchronization Scheme. IEEE Trans. Power Syst. 2018, 33, 4994-5005. [CrossRef]

163. Sun, C.; Joos, G.; Bouffard, F. Control of Microgrids with Distributed Energy Storage Operating in Islanded Mode. In Proceedings of the 2017 IEEE Electrical Power and Energy Conference (EPEC), Saskatoon, SK, Canada, 22-25 October 2017.

164. Khan, M.W.; Wang, J. The research on multi-agent system for microgrid control and optimization. Renew. Sustain. Energy Rev. 2017, 80, 1399-1411. [CrossRef]

165. Twining, E.; Holmes, D.G. Grid current regulation of a three-phase voltage source inverter with an LCL input filter. IEEE Trans. Power Electron. 2003, 18, 888-895. [CrossRef]

166. Li, W.; Wang, S.; Koo, C. A real-time optimal control strategy for multi-zone VAV air-conditioning systems adopting a multi-agent based distributed optimization method. Appl. Energy 2021, 287, 116605. [CrossRef]

167. Sidiropoulos, G. Metis: Multi-Agent Based Crisis Simulation System. arXiv 2020, arXiv:2009.03934.

168. Abdelgawad, H. A Comprehensive Review on Microgrid Architectures for Distributed Generation. In Proceedings of the 2019 IEEE Electrical Power and Energy Conference (EPEC), Montreal, QC, Canada, 16-18 October 2019; Volume 3.

169. Hassan, S.R.M.; Hasan, N.; Siddique, M.A.; Fahim, K.S.; Rahman, R.; Iftekhar, L. Incorporating Multi-Agent Systems Technology in Power and Energy Systems of Bangladesh:A Feasibility Study. In Proceedings of the 2021 2nd International Conference on Robotics, Electrical and Signal Processing Techniques (ICREST), Dhaka, Bangladesh, 5-7 January 2021; pp. 342-347. [CrossRef]

170. Bui, V.H.; Hussain, A.; Kim, H.M. A multiagent-based hierarchical energy management strategy for multi-microgrids considering adjustable power and demand response. IEEE Trans. Smart Grid 2018, 9, 1323-1333. [CrossRef]

171. Foundation of Intelligent Physical Agents (FIPA). 2020. Available online: http:/ / www.fipa.org/ (accessed on 19 July 2021).

172. Krishnakumar R., V.; Vigna, K.R.; Gomathi, V.; Ekanayake, J.B.; Tiong, S.K. Modelling and simulation of variable speed pico hydel energy storage system for microgrid applications. J. Energy Storage 2019, 24, 100808. [CrossRef]

173. Phan-Tan, C.T.; Hill, M. Decentralized Optimal Control for Photovoltaic Systems Using Prediction in the Distribution Systems. Energies 2021, 14, 3973. [CrossRef]

174. Naji Alhasnawi, B.; Jasim, B.H.; Anvari-Moghaddam, A.; Blaabjerg, F. A New Robust Control Strategy for Parallel Operated Inverters in Green Energy Applications. Energies 2020, 13, 3480. [CrossRef]

175. Ustun, T.; Aoto, Y.; Hashimoto, J.; Otani, K. Optimal PV-INV Capacity Ratio for Residential Smart Inverters Operating Under Different Control Modes. IEEE Access 2020, 8, 116078-116089. [CrossRef]

176. Al-Ammar, E.A.; Habib, H.U.R.; Kotb, K.M.; Wang, S.; Ko, W.; Elmorshedy, M.F.; Waqar, A. Residential Community Load Management Based on Optimal Design of Standalone HRES With Model Predictive Control. IEEE Access 2020, 8, 12542-12572. [CrossRef]

177. Gangatharan, S.; Rengasamy, M.; Elavarasan, R.M.; Das, N.; Hossain, E.; Sundaram, V.M. A Novel Battery Supported Energy Management System for the Effective Handling of Feeble Power in Hybrid Microgrid Environment. IEEE Access 2020, 8, 217391217415. [CrossRef]

178. Chishti, F.; Murshid, S.; Singh, B. PCC Voltage Quality Restoration Strategy of an Isolated Microgrid Based on Adjustable Step Adaptive Control. IEEE Trans. Ind. Appl. 2020, 56, 6206-6215. [CrossRef]

179. Garces, A. Small-signal stability in island residential microgrids considering droop controls and multiple scenarios of generation. Electr. Power Syst. Res. 2020, 185, 106371. [CrossRef]

180. Raza, S.A.; Jiang, J. A Benchmark Distribution System for Investigation of Residential Microgrids With Multiple Local Generation and Storage Devices. IEEE Open Access J. Power Energy 2020, 7, 41-50. [CrossRef]

181. Bozalakov, D.; Laveyne, J.; Desmet, J.; Vandevelde, L. Overvoltage and voltage unbalance mitigation in areas with high penetration of renewable energy resources by using the modified three-phase damping control strategy. Electr. Power Syst. Res. 2019, 168, 283-294. [CrossRef]

182. Arab, N.; Kedjar, B.; Javadi, A.; Al-Haddad, K. A Multifunctional Single-Phase Grid-Integrated Residential Solar PV Systems Based on LQR Control. IEEE Trans. Ind. Appl. 2019, 55, 2099-2109. [CrossRef]

183. Habib, H.U.R.; Wang, S.; Elkadeem, M.R.; Elmorshedy, M.F. Design Optimization and Model Predictive Control of a Standalone Hybrid Renewable Energy System: A Case Study on a Small Residential Load in Pakistan. IEEE Access 2019, 7, 117369-117390. [CrossRef]

184. Wang, L.; Yan, R.; Saha, T.K. Voltage regulation challenges with unbalanced PV integration in low voltage distribution systems and the corresponding solution. Appl. Energy 2019, 256, 113927. [CrossRef]

185. Raza, S.A.; Jiang, J. Intra- and Inter-Phase Power Management and Control of a Residential Microgrid at the Distribution Level. IEEE Trans. Smart Grid 2019, 10, 6839-6848. [CrossRef]

186. Kumar, S.; Singh, B. Self-Normalized-Estimator-Based Control for Power Management in Residential Grid Synchronized PV-BES Microgrid. IEEE Trans. Ind. Inform. 2019, 15, 4764-4774. [CrossRef] 
187. Jafari, M.; Malekjamshidi, Z.; Lu, D.D.C.; Zhu, J. Development of a Fuzzy-Logic-Based Energy Management System for a Multiport Multioperation Mode Residential Smart Microgrid. IEEE Trans. Power Electron. 2019, 34, 3283-3301. [CrossRef]

188. Tran, V.T.; Muttaqi, K.M.; Sutanto, D. A Robust Power Management Strategy With Multi-Mode Control Features for an Integrated PV and Energy Storage System to Take the Advantage of ToU Electricity Pricing. IEEE Trans. Ind. Appl. 2019, 55, 2110-2120. [CrossRef]

189. Ustun, T.S.; Aoto, Y. Analysis of Smart Inverter's Impact on the Distribution Network Operation. IEEE Access 2019, 7, 9790-9804. [CrossRef]

190. Hafiz, F.; de Queiroz, A.R.; Husain, I. Coordinated Control of PEV and PV-Based Storages in Residential Systems under Generation and Load Uncertainties. IEEE Trans. Ind. Appl. 2019, 55, 5524-5532. [CrossRef]

191. Khamis, A.K.; Zakzouk, N.E.; Abdelsalam, A.K.; Lotfy, A.A. Decoupled Control Strategy for Electric Springs: Dual Functionality Feature. IEEE Access 2019, 7, 57725-57740. [CrossRef]

192. Zunnurain, I.; Maruf, M.; Rahman, M.; Shafiullah, G. Implementation of Advanced Demand Side Management for Microgrid Incorporating Demand Response and Home Energy Management System. Infrastructures 2018, 3, 50. [CrossRef]

193. Chamandoust, H.; Hashemi, A.; Derakhshan, G.; Hakimi, M. Scheduling of Smart Micro Grid Considering Reserve and Demand Side Management. In Proceedings of the 2018 Smart Grid Conference (SGC), Sanandaj, Iran, 28-29 November 2018; pp. 1-8. [CrossRef]

194. Chamandoust, H.; Bahramara, S.; Derakhshan, G. Day-ahead scheduling problem of smart micro-grid with high penetration of wind energy and demand side management strategies. Sustain. Energy Technol. Assess. 2020, 40, 100747. [CrossRef]

195. Davarzani, S.; Pisica, I.; Taylor, G.A.; Munisami, K.J. Residential Demand Response Strategies and Applications in Active Distribution Network Management. Renew. Sustain. Energy Rev. 2021, 138, 110567. [CrossRef]

196. Wang, X.; Wang, H.; Ahn, S.H. Demand-side management for off-grid solar-powered microgrids: A case study of rural electrification in Tanzania. Energy 2021, 224, 120229. [CrossRef]

197. Imani, M.H.; Talouki, M.Y.; Niknejad, P.; Yousefpour, K. Running direct load control demand response program in microgrid by considering optimal position of storage unit. In Proceedings of the 2018 IEEE Texas Power and Energy Conference (TPEC), College Station, TX, USA, 8-9 February 2018; pp. 1-6. [CrossRef]

198. Imani, M.H.; Yousefpour, K.; Andani, M.T.; Ghadi, M.J. Effect of Changes in Incentives and Penalties on Interruptible/Curtailable Demand Response Program in Microgrid Operation. In Proceedings of the 2019 IEEE Texas Power and Energy Conference (TPEC), College Station, TX, USA, 7-8 February 2019; pp. 1-6. [CrossRef]

199. Nikzad, M.; Samimi, A. Integration of designing price-based demand response models into a stochastic bi-level scheduling of multiple energy carrier microgrids considering energy storage systems. Appl. Energy 2021, 282, 116163. [CrossRef]

200. Wang, Y.; Huang, Y.; Wang, Y.; Zeng, M.; Li, F.; Wang, Y.; Zhang, Y. Energy management of smart micro-grid with response loads and distributed generation considering demand response. J. Clean. Prod. 2018, 197, 1069-1083. [CrossRef]

201. Esan, A.B.; Oghorada, O.; Agbetuyi, A.F. Conceptual model framework for demand response ancillary services deployed by inter-connected microgrids in West Africa-A Nigerian case study. Renew. Energy Focus 2020, 34, 47-56. [CrossRef]

202. Hosseini Imani, M.; Niknejad, P.; Barzegaran, M.R. The impact of customers' participation level and various incentive values on implementing emergency demand response program in microgrid operation. Int. J. Electr. Power Energy Syst. 2018, 96, 114-125. [CrossRef]

203. Nikzad, M.; Samimi, A. Integration of Optimal Time-of-Use Pricing in Stochastic Programming for Energy and Reserve Management in Smart Micro-grids. Iran. J. Sci. Technol. Trans. Electr. Eng. 2020, 44, 1449-1466. [CrossRef]

204. Shehzad Hassan, M.A.; Chen, M.; Lin, H.; Ahmed, M.H.; Khan, M.Z.; Chughtai, G.R. Optimization modeling for dynamic price based demand response in microgrids. J. Clean. Prod. 2019, 222, 231-241. [CrossRef]

205. Gazijahani, F.S.; Salehi, J. Reliability constrained two-stage optimization of multiple renewable-based microgrids incorporating critical energy peak pricing demand response program using robust optimization approach. Energy 2018, 161, 999-1015. [CrossRef]

206. Tsaousoglou, G.; Efthymiopoulos, N.; Makris, P.; Arigos, E.V. Personalized real time pricing for efficient and fair demand response in energy cooperatives and highly competitive flexibility markets. J. Mod. Power Syst. Clean Energy 2019, 7, 151-162. [CrossRef]

207. Leong, C.H.; Gu, C.; Li, F. Auction Mechanism for P2P Local Energy Trading considering Physical Constraints. Energy Procedia 2019, 158, 6613-6618. [CrossRef]

208. Hassan, A.; Acharya, S.; Chertkov, M.; Deka, D.; Dvorkin, Y. A Hierarchical Approach to Multienergy Demand Response: From Electricity to Multienergy Applications. Proc. IEEE 2020, 108, 1457-1474. [CrossRef]

209. Andrei, H.; Gaiceanu, M.; Stanculescu, M.; Arama, I.N.; Andrei, P.C., Power Systems Connectivity and Resiliency. In Power Systems Resilience: Modeling, Analysis and Practice; Mahdavi Tabatabaei, N., Najafi Ravadanegh, S., Bizon, N., Eds.; Springer International Publishing: Cham, Switzerland, 2019; pp. 45-79._2. [CrossRef]

210. Goetzler, B.; Guernsey, M.; Kassuga, T.; Young, J.; Savidge, T.; Bouza, A.; Neukomm, M.; Sawyer, K. Grid-Interactive Efficient Buildings Technical Report Series: Heating, Ventilation, and Air Conditioning (HVAC); Water Heating; Appliances and Refrigeration; National Renewable Energy Lab. (NREL): Golden, CO, USA, 2019. [CrossRef]

211. Tulabing, R.; Yin, R.; DeForest, N.; Li, Y.; Wang, K.; Yong, T.; Stadler, M. Modeling study on flexible load's demand response potentials for providing ancillary services at the substation level. Electr. Power Syst. Res. 2016, 140, 240-252. [CrossRef] 
212. de Christo, T.M.; Perron, S.; Fardin, J.F.; Simonetti, D.S.L.; de Alvarez, C.E. Demand-side energy management by cooperative combination of plans: A multi-objective method applicable to isolated communities. Appl. Energy 2019, 240, 453-472. [CrossRef]

213. Isa, N.M.; Tan, C.W.; Yatim, A.H.M. A comprehensive review of cogeneration system in a microgrid: A perspective from architecture and operating system. Renew. Sustain. Energy Rev. 2018, 81, 2236-2263. [CrossRef]

214. Martins, M.A.I.; Fernandes, R.; Heldwein, M.L. Proposals for Regulatory Framework Modifications for Microgrid Insertion-The Brazil Use Case. IEEE Access 2020, 8, 94852-94870. [CrossRef]

215. Sedhom, B.; El-Saadawi, M.; Hatata, A.; Abd-Raboh, E. A Review on Control Schemes for Grid Connected and Islanded Microgrid. J. Electr. Eng. 2019, 19, 16.

216. Ghafouri, A.; Milimonfared, J.; Gharehpetian, G.B. Coordinated Control of Distributed Energy Resources and Conventional Power Plants for Frequency Control of Power Systems. IEEE Trans. Smart Grid 2015, 6, 104-114. [CrossRef]

217. Logenthiran, T.; Naayagi, R.T.; Woo, W.L.; Phan, V.T.; Abidi, K. Intelligent Control System for Microgrids Using Multiagent System. IEEE J. Emerg. Sel. Top. Power Electron. 2015, 3, 1036-1045. [CrossRef]

218. Han, Y.; Zhang, K.; Li, H.; Coelho, E.A.A.; Guerrero, J.M. MAS-Based Distributed Coordinated Control and Optimization in Microgrid and Microgrid Clusters: A Comprehensive Overview. IEEE Trans. Power Electron. 2018, 33, 6488-6508. [CrossRef] 